\title{
Türk Mimarisinde Çapraz "X” Motif ve İkonografisi
}

\author{
Alev ÇAKMAKOĞLU-KURU ${ }^{1}$ \\ Öz
}

Kaynağı Orta Asya'da bulunan Türk Sanatının yeryüzünün farklı coğrafyalarında varlık gösteren binlerce yıllık yolculuğundaki eserlerinde aynı ya da benzer motiflere farklı dönem üslupları içerisinde yer verildiği görülmektedir. Taşınabilir nitelikte olanlarda, mimarlık eserlerinde karşımıza çıkan bu motifler kaya resimlerinden mezar taşlarına, keçelerden, halı ve kilimlere, maden ve ahşap eserlerden kümbet, türbe ve camilere daha nicelerine yansiyan Türk izleridir. Bu motifler kimi zaman üzerindeki esere bir aidiyet damgasını, mührünü vururken kimi zaman taşıdığ1 anlamla bir seslenişi, bazen da her ikisini beraberinde barındırırlar. Bazı motifler pek çok kültürde yer bulmuş olsa da hatta evrensel bir dili olsa da her milletin aynı motife kattığı anlam, süsleme programları içerisinde yer veriş şekli farkllık gösterebilmektedir. Zamanın süzgecinden geçen böyle motifler duyulardaki bellekteki izleri ile yaşamaya devam ederler. İște bu makalede böyle motiflerden birinin, birbirini verev kesen iki çizginin oluşturduğu çarpraz olarak nitelenen " $\mathrm{X}$ " şeklindeki motifin Türk eserlerinde özellikle mimarideki yer alışı ve ikonografisinin üzerinde durulmaktadir.

Anabtar Kelimeler: Türk Mimarisi, Türk Sanatı, Süsleme, Motif, Çapraz, İkonografi

\section{Cross "X" Motif and Iconography in Turkish Architecture}

\begin{abstract}
It is seen that the same or similar motifs are included in different period styles in the works of Turkish Art, which originates in Central Asia, on thousands of years of journey in different geographies of the earth. In the ones that are portable, these motifs that we encounter in architectural works are Turkish traces reflected from rock paintings to tombstones, felts, carpets and rugs, mines and wooden works, to cupolas, tombs and mosques. These motifs sometimes bear a hallmark of belonging to the work on it, a call to the meaning they carry while their seal, and sometimes both. Although some motifs have found place in many cultures, even if they have a universal language, the meaning that every nation adds to the same motif and the way it is included in the decoration programs may differ. Such motifs passing through the filter of time continue to live with their traces in memory in the senses. In this article, the "X" shaped motif, which is described as a cross formed by two cross-cutting lines of one of such motifs, in Turkish works, especially its place in architecture and iconography are emphasized.
\end{abstract}

Key Words: Turkish Architecture, Turkish Art, Decoration, Motif, Cross, Iconography

Atıf İçin / Please Cite As:

Çakmakoğlu-Kuru, A. (2020). Türk mimarisinde çapraz "X" motif ve ikonografisi. Manas Sosyal Araşttrmalar Dergisi, 9(4), 2263-2285.

Geliş Tarihi / Received Date: 31.03.2020

Kabul Tarihi / Accepted Date: 18.05.2020 


\section{Giriş}

X” şeklinde taş oymaların Türklerin tarih sahnesine çıktıkları Orta Asya'dan Anadolu'ya, Paleolitik çağdan itibaren kaya resimlerinde yer aldığ1 görülmektedir (Foto: 1, Şekil: 1), (Somuncuoğlu, 2010, s. 20). Hun dönemine ait Pazırık kurganından çıkan Türklerin ve dünyanın en eski halısında merkezdeki yirmi dört karenin içinde yer alan çapraz çiçek ve yapraklardan oluşan "Hun gülü -Hun gölü” denilen motif sonraki dönemlerde Türk halılarında varlığını devam ettirecektir (Foto: 2, Şekil: 2) (Kırzıŏlu, 1995, s. 30).

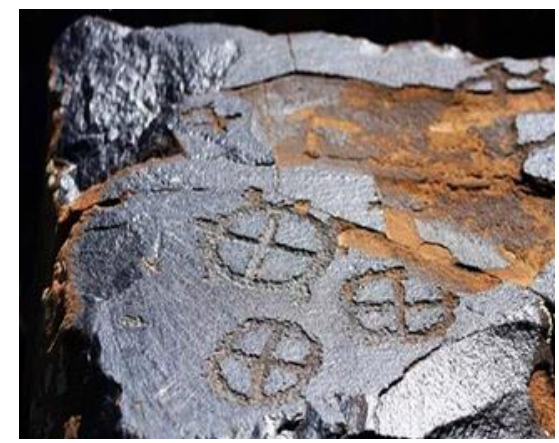

Fotoğraf 1. Saymalitaş (Somuncuoğlu)

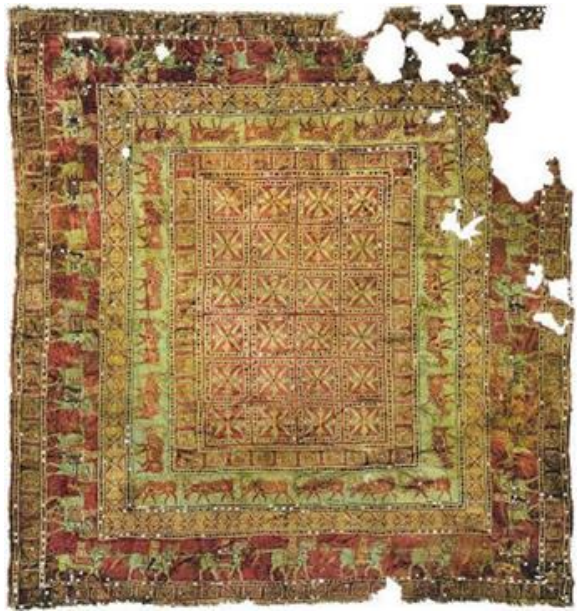

Fotoğraf 2. Pą̧ırk Halısı

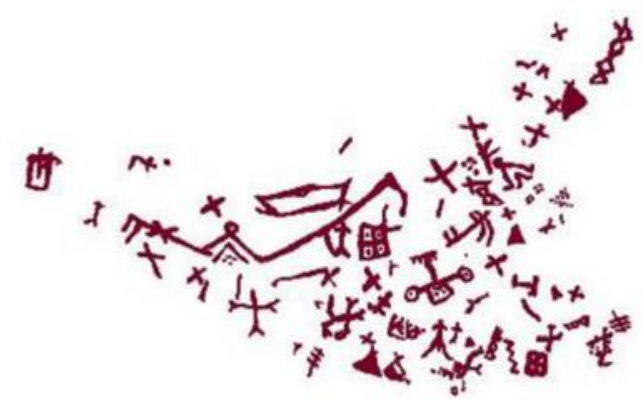

Şekil 1. Akbaur Mağarası (Z. S. Samaşev)

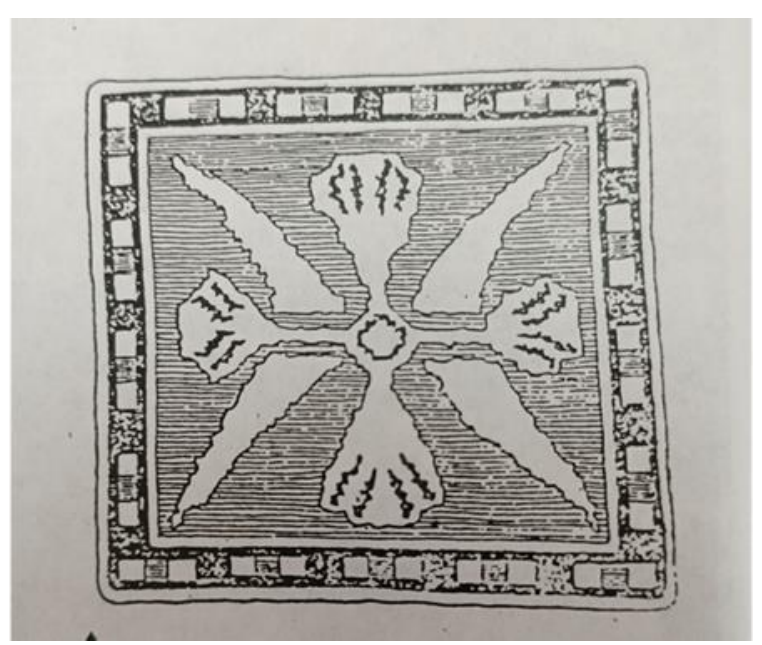

Şekil 2. Hun Gülü-Hun Gölü (N. Görgünay)

Göktürkler zamanında Orta Asya coğrafyasında dikilmiş olan sayısız “geyikli taşların” üzerlerinde de çapraz çizgiler bulunmakta, yine Göktürklere ait olduğu düşünülen Pencikent Duvar Resimlerinde(7-8. yy) yer alan Yuğ Töreni Tasviri'nde sağ üstte kaya resimlerinde de rastlandı̆̆1 üzere daire içinde "X" işareti dikkat çekmektedir (Şekil: 3), (Cezar, 1977, s. 259; İskenderzade, 2010, s. 257).

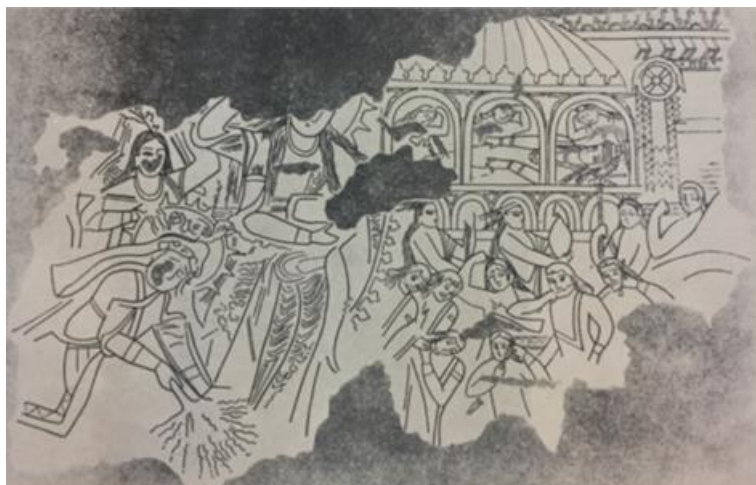

Şekil 3. Pencikent Sarayı Duvar Resmi (M. Cezar)

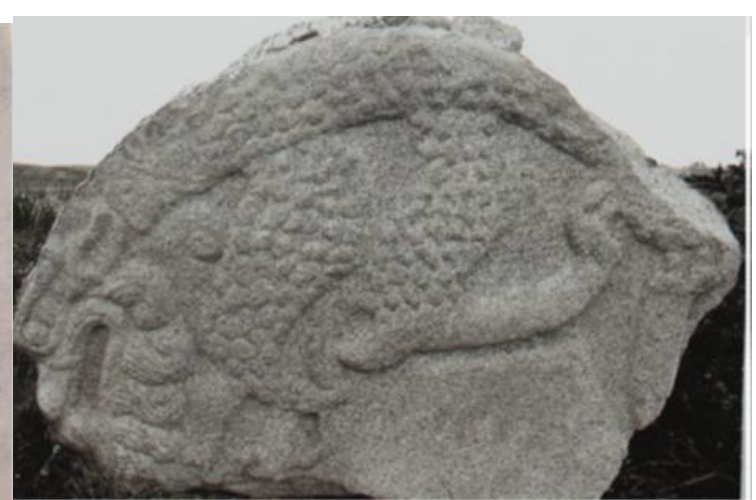

Fotoğraf 3. Karabalgasun Yaz̨ıtı (Somuncuoğlu)

840’lı y1llara ait olduğu düşünülen Uygur yazıtlarının en önemlilerinden Karabalsagun Yazıtının tepelik kısmında yer alan ejder kabartmasının boynunda "X" şeklinde kabartma bulunmaktadır (Foto:3 ) (Ölmez, 2012, s. 215; Somuncuoğlu, 2010, s. 171) 


\section{Türk Mimarisinde Çapraz Motifler}

İslamiyet'i kabul eden Türkler'in ilk devletleri olarak bilinen Karahanlı döneminde de "X" şekline özellikle mimaride, özellikle tuğla süslemelerinde rastlanmaktadır. Özbekistan, Buhara'da Muğak Attârî Camii (9-12. yy) taç kapısı duvarlarındaki tuğla bezemede, 12. yy'a ait Buhara Namazgâhında batı duvarının tuğla süslemelerinde, Kalan Minaresinin (1127) gövdesinde tuğla arasındaki derz baskılarında kesim noktasında enlemesine birer çizgiye sahip çapraz şekilli kabartmaların yer aldığı görülmektedir (Çeşmeli, 2005). Aynı motifler Tirmiz Sultan Sedât Türbesinde (12. yy-14. yy) mavi sırlı ve sırsız tuğla süslemelerde karşımıza çıkmaktadır. Özkent Nasır bin Ali yani Orta Türbesi (1012-13) güney cephesinde tuğla örgüler arasında birbirini çapraz kesen dört yapraklı bitkisel motifler şeklinde bezemelere sahipken, türbenin arka tarafinda duvar yüzeyinde sekiz köşeli yıldızlar aralarında "X" şekilli tuğla kabartmalarla yer almaktadır. Kazakistan'ın Cambul Eyaleti Taraz Şehrine yakın Ayşe Bibi Türbesinin (12. yy) tuğla cephelerinde terrakota levhalarda oyma ve bask1 teknikleri uygulanarak meydana getirilen çapraz motifler Pazırık halısında yer alan Hun gülü motifini hatırlatmaktadır (Koshenova, 2013, s. 46),( Şekil: 4-6) (Foto: 4-8).

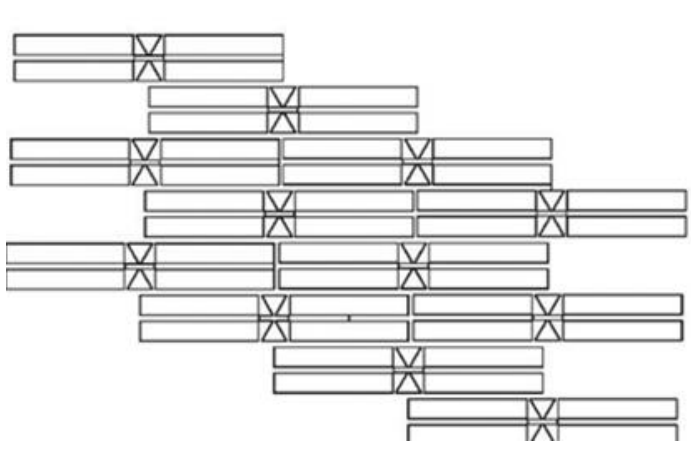

Şekil 4. Muğâke-ı Attârî Camii Taçkapısı Duvarlarındaki Tuğla Bezeme

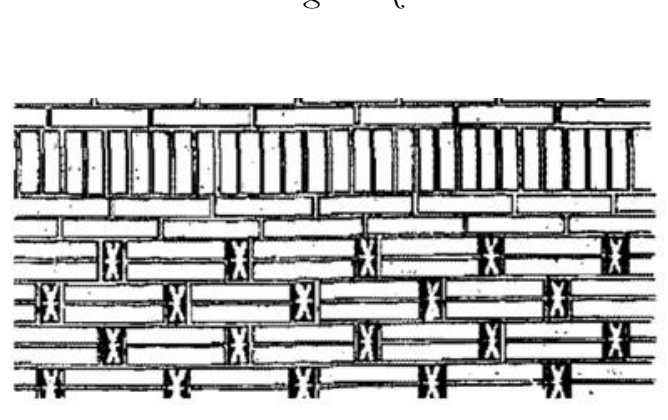

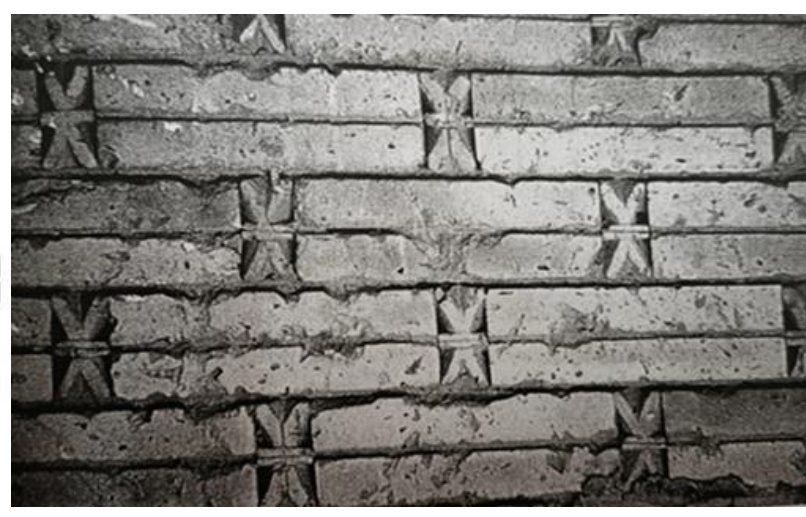

Fotoğraf 4. Buhara Namazgahında Tuğla Örgüsü (I. Çeşmeli)

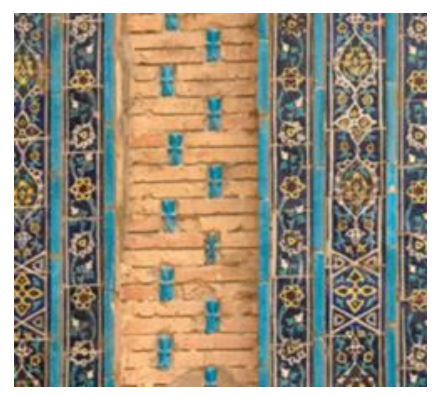

Şekil 5. Kalan Minaresi

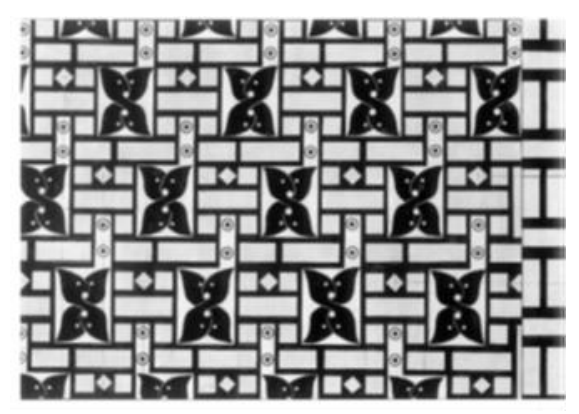

Şekil 6. Ö₹kent Orta Türbesi
Fotoğraf 5. Tirmiz Sultan Sedât Türbesi (Imankulov)

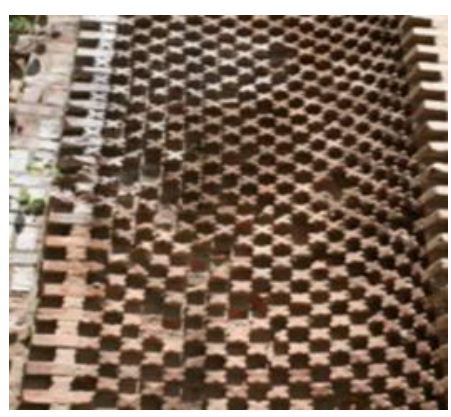

Fotoğraf 6. Özkent Orta Türbesi'nin Arka Duvarn (Imankulov) 


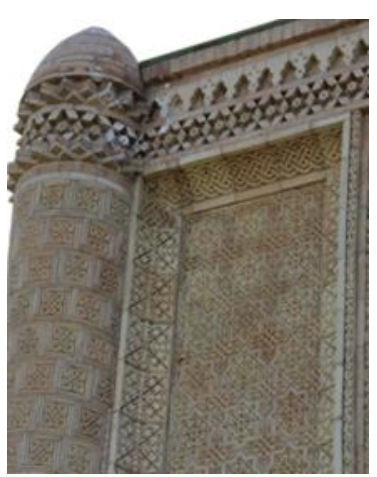

Fotoğraf 7. Aysse Bibi Türbesi

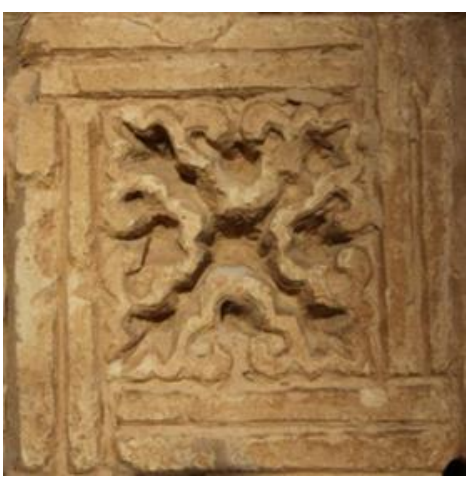

Fotoğraf 8. Ayșe Bibi Türbesi Terrakota Süslemelerden

Gazneliler zamanında yapılan, Karahanlıların 12. yy başlarında tamir ederek duvar panolarını yeniden ele aldığı Tirmiz Karahanlı Köşkü’ndeki geometrik düzenlemede ilk bakışta dört yöne uzanan ok ucu şeklinde motifler fark edilse bile dikkat edildiğinde bu motifleri oluşturan kabartma şeritlerin birbirine yatay ve dikey tutunarak ilerleyen çapraz geçmelerden meydana gelmiş olduğu anlaşılmaktadır. Güney Türkmenistan'da Başane Ulu Camiinin (11. yy ilk yarısı- 12. yy)küçük kare tuğlalarla kaplı mihrap nişinde münavebeli olarak üzerinde " $X$ " şeklinde kabartmaları olan motifler yer almaktadır. Karahanlılara ait Merv, Talhatan Baba Camisinin(11.yy sonu 12. yy. başl.) güneybatı cephesinde de tuğla dizilimlerin oluşturduğu eşkenar dörtgen alanlarda üzerlerinde çapraz motifler bulunan küçük kareler münavebeli olarak sıralanmışlardır. Aynı şekilde çapraz motiflere güney Kazakistan'da eski Keder şehri harabelerinde 11-12 yy’a ait tuğla süslemelerde de rastlanmaktadır. Özbekistan'ının güneyinde Şurci Şehri'nin kuzeydoğusunda Sapol Tepe denilen eski şehir harabesinde yer alan Camide yapılan araştırmalar sonucu tuğla süslemeler arasında "X" şeklinde olanlara da rastlanmıştır (Çeşmeli, 2005; Rustamova, 2019). Karahanlı döneminde çapraz şekilli motiflerin Türk Sanatında, Türk Mimarlık süslemeleri arasında bu şekilde yer alışı Türk Tarihinin diğer dönemlerinde de devamll11k göstermektedir (Şekil: 7) (Foto: 9).

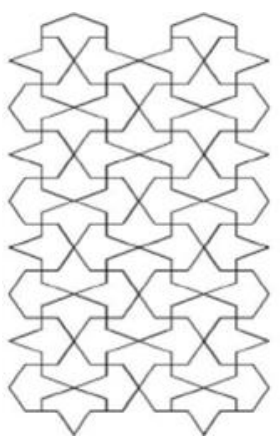

Şekil 7. Tirmiそ Köskë̈ (İmankulov)

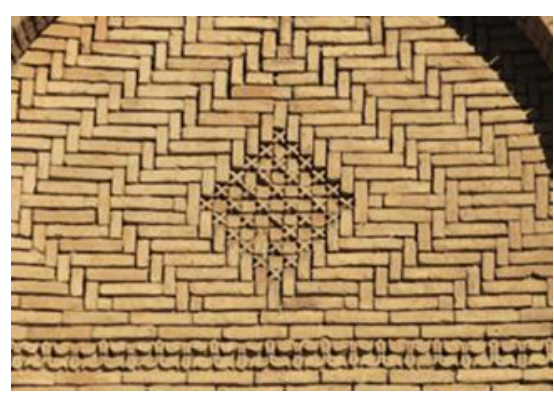

Fotoğraf 9. Talhatan Baba Camii

Büyük Selçuklu Dönemine ait Isfahan Cuma Camisinin (11-12. yy) payelerindeki tuğla dizilimlerin derzlerinde ve Terken Hatun kubbesinde, Ardistan Mescidi Cuma Camisi (12. yy) mihrap önü kubbesinde görüldüğü üzere tuğlaların oluşturduğu eşkenar dörtgenlerin ortalarında ve tuğla duvar örgülerinde çapraz motifler yer almaya devam etmiştir. (Foto: 10-12) 


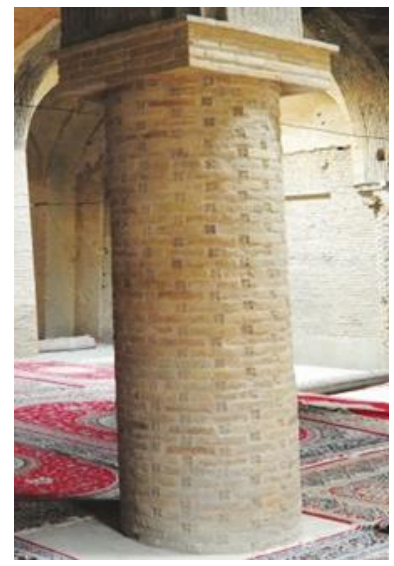

Fotoğraf 10. Isfahan Mescid-i Cumast

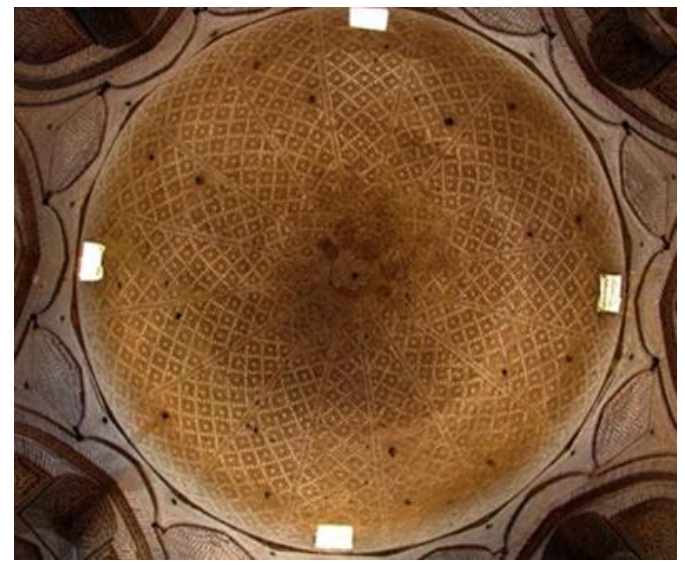

Fotoğraf 11. Ardistan Mescid-i Cuma Kubbesi

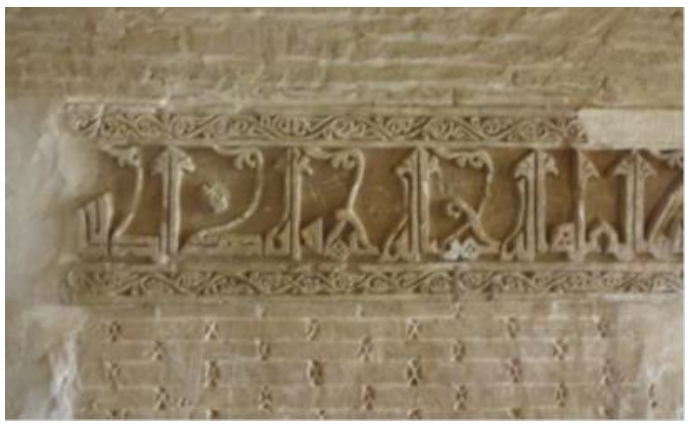

Fotoğraf 12. Ardistan Cuma Camisi Derẓler

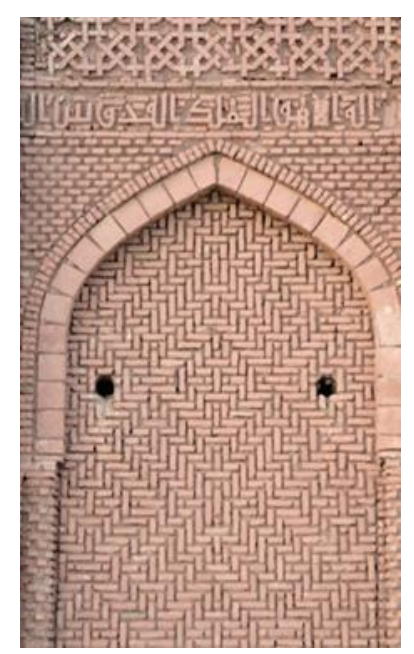

Fotoğraf 13. Karagan Kümbeti

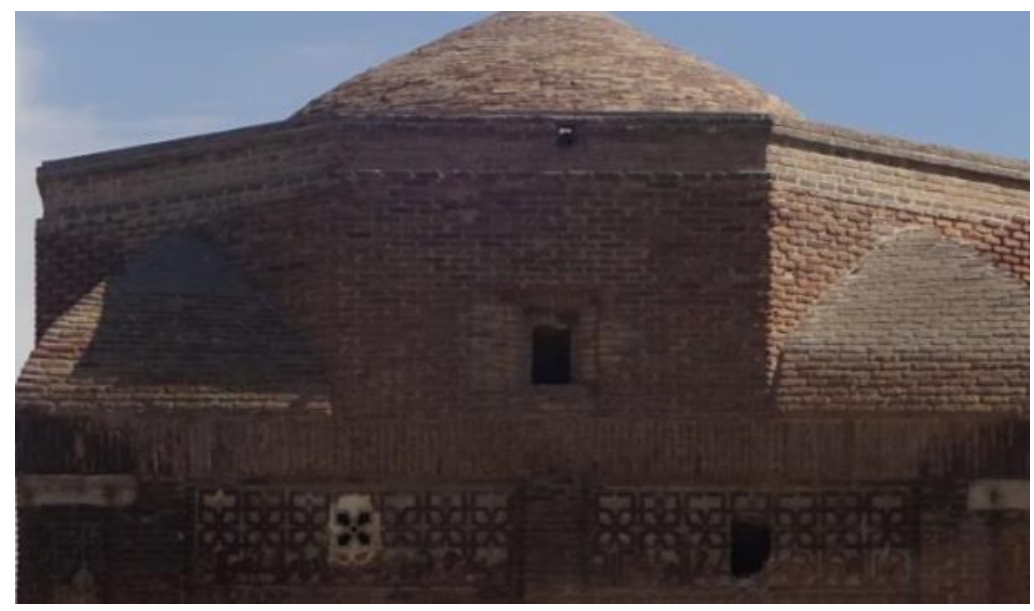

Fotoğraf 14. Kümbet-i Surh (Sepideh Heiranpour)

Büyük Selçuklulara ait sekizgen gövdeli Karagan Kümbetlerinden doğudaki (1067-68) ile batıdaki (1093) ve Meraga, Kümbeti Surh’un (1148) tuğla duvar örgülerinde "X” şeklinde motiflerin oluştuğu da görülmektedir (Foto: 13) (Ali, 1390, s. 166-186; Heiranpour, 2019). Ayrica Kümbeti Surh'da cepheleri sınırlayan kitabe kuşağında kabartma şeritler, üstte çapraz oluşturacak şekilde geçmeler yaparak ilerlemektedir (Foto: 14).Bu şekildeki çapraz kabartmalar 1281 tarihli Radkan Kümbetinde yivli gövdenin üstünde külah altındaki turkuaz çinilerin yer aldığ1 kitabe kuşağının bulunduğu silindirik bölümünde de karşımıza çıkmaktadır(Foto: 15). 


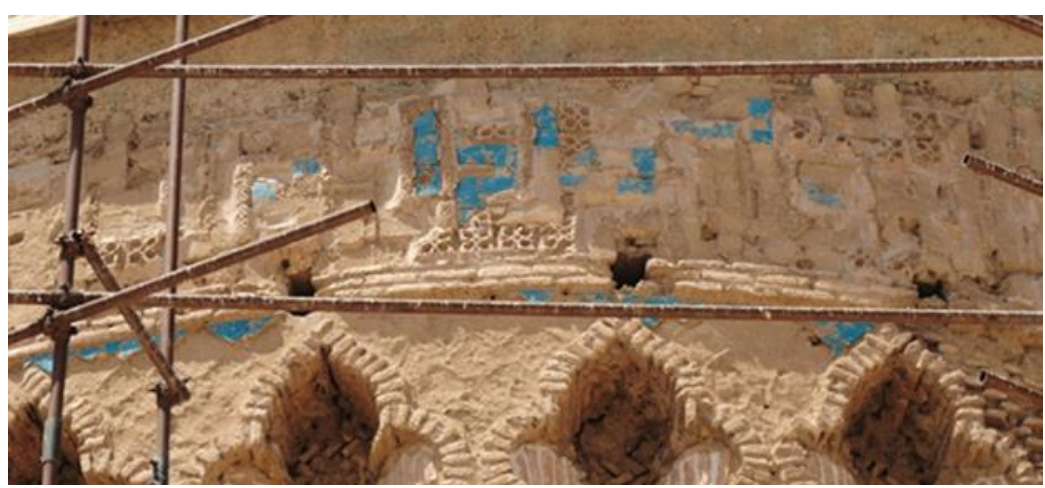

Fotoğraf 15. Radkan Kümbet

Damgan, Cihil Duhteran Kümbeti'nin (1054-55)silindirik gövdesinin üst kısmında yer alan kitabe kuşağını sınırlayan iki kenarsuyunda ise çarkıfelek motifleri çapraz hatlarla birbirlerine bağlanarak ilerlemektedir (Foto: 16). Büyük Selçuklu dönemine ait Ribatı Şerif Kervansarayında(1114-15),Serahs Yartı Kümbet'de(1098) alçı yüzeylerde çapraz şekilli baskıların kullanıldığ1 görülmektedir(Foto: 17, 18).

Türkistan, Horasan ve Orta İran bölgelerinde 10.yy.'dan başlayarak pek çok yapıda tuğla dizilimlerinin düşey derz aralarında ahşap kalıpla oluşturulan ortalarına birer halkanın ilmiklendiği iki çapraz çizgiden ibaret motif uygulaması Anadolu Selçuklu dönemine ait Kemah Mengücek Gazi Türbesinde (12. yy sonu13. yy başı) olduğu üzere varlığını sürdürecektir. Bu kümbetin mumyalık katında tonoz üst örtüye birleşen sekizgen ayağın tuğla derz aralarında, ortalarında birer halka ilmiklenen iki çapraz çizginin oluşturduğu motiflerle karşılaşılmaktadır (Foto: 19), (Bakırer, 2002, s. 6).

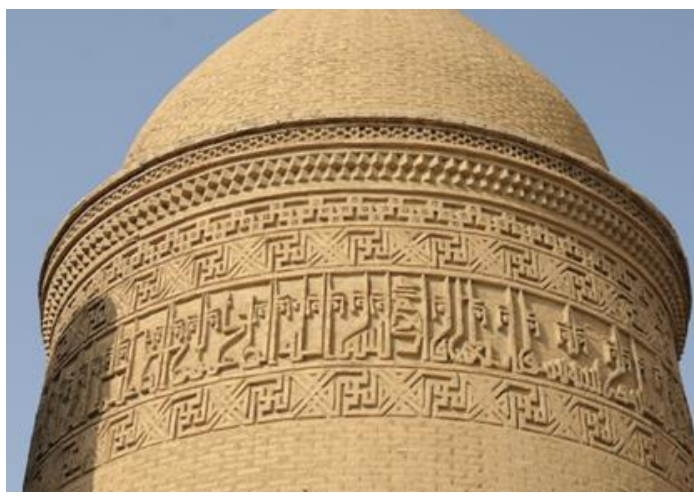

Fotoğraf 16. Cibil Dubteran Kümbeti

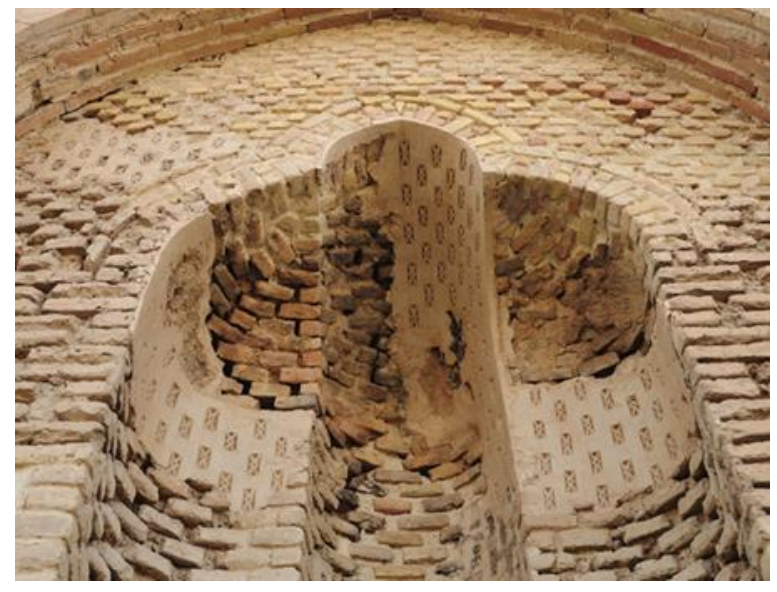

Fotoğraf 17. Ribat-ı Şerif
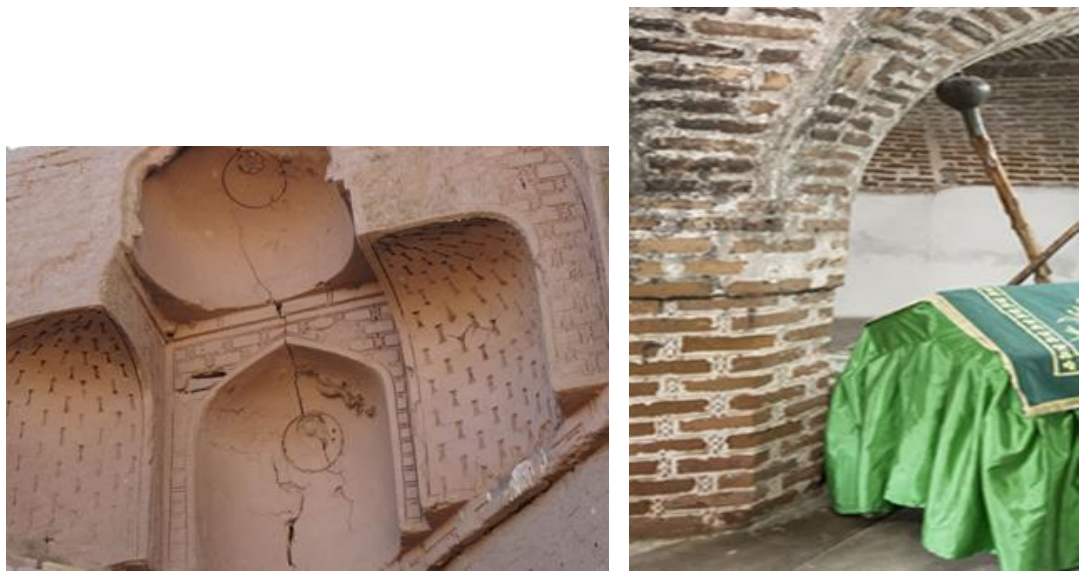

Fotoğraf 18. Serahs, Yart Kümbet

Fotoğraf 19. Kemah Mengücek Gąi Türbesi(Mustafa Turgut) 
Tirmiz Karahanlı Köşkünde gördüğümüz üzere kırık hatlı çizgilerin kesişmeleri sonucu, yatayda karşılıklı, dikeyde ise ters yönde ok uçları meydana gelen geometrik süslemeler, Erzurum Emir Saltuk Kümbeti (12. yy sonu) ile Amasya Halifet Gazi Kümbetinin(1210) taç kapısını çevreleyen kenarsuyunda olduğu gibi Anadolu'daki mimari örneklerde sıkça kullanılmıștır (Foto: 20, 21) (Baş, 2013, s. 405, Foto 158-159). Bu süslemede ok uçlarını dikey ve yatay hatlarda " $\mathrm{X}$ " şeklindeki motiflerin oluşturduğu dikkat çekmektedir. Menteşeli Beyliğine ait Balat İlyas Bey Camii (1404) doğu duvarının kuzey üst penceresindeki süslemeler ile batı duvarın kuzey alt penceresindeki alınlık süslemelerinde daha önce Karahanlı dönemi yapılarında da görüldüğü üzere alternatif olarak yatay ve düşey hatlarda birbirine tutunarak ilerleyen " $\mathrm{X}$ " şeklinde kabartma şeritler yer almakta ve bu şeritler ok uçları meydana getirmektedirler (Bozkurt, 2016,s.34). Amasya Gümüş Hacı Halil Paşa Medresesi(1413-1415) güney kanadındaki dershanenin giriş açıklı̆̆ını örten atkı taşının üzerindeki süslemedeki aynı geometrik düzen Akkoyunlulara ait Diyarbakır, Şeyh Safa Camii (1401-1515) minaresinin gövdesindeki geometrik süslemeli panolar arasinda, minber korkuluğunda da yer almaktadır (Şekil: 10) (Demiralp, 1997, s. 57, Şekil: 32), (Sözen, 1971, s. 48).

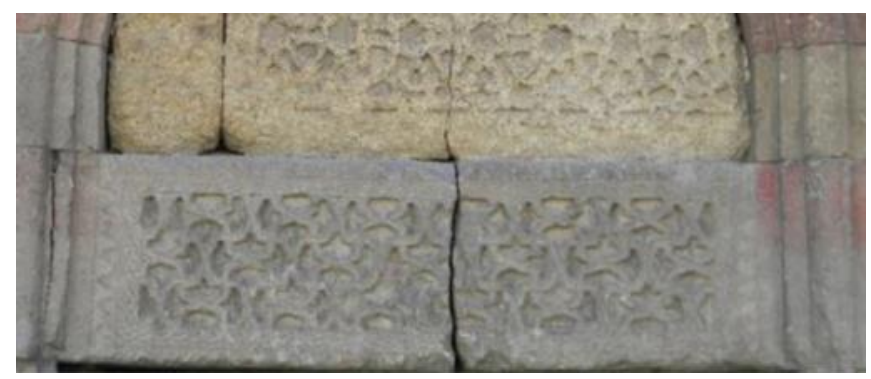

Fotoğraf 20. Eræurum, Emir Saltuk. Kümbeti Taçkapı Lentosu (G.Bass)

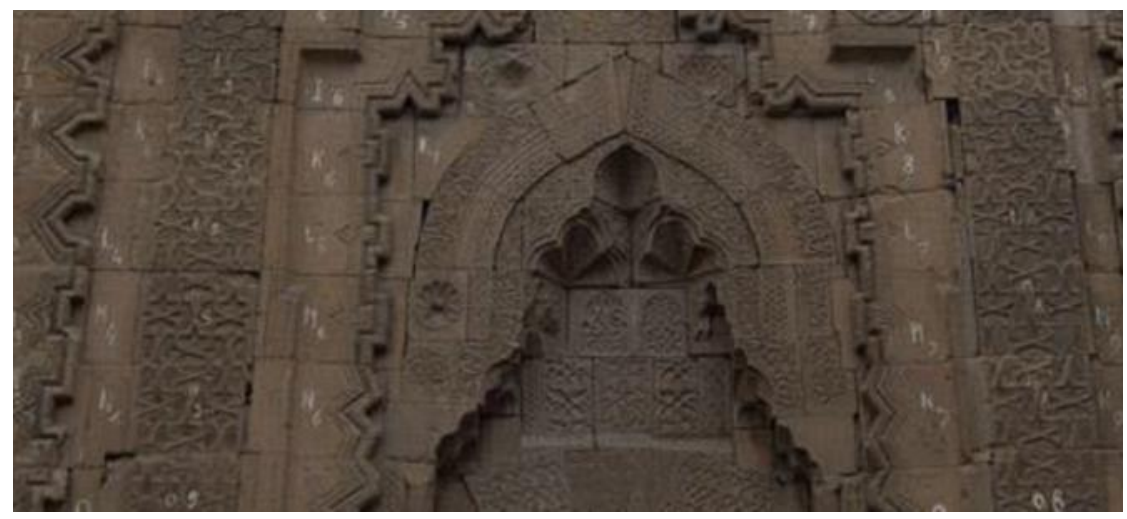

Fotoğraf 21. Amasya Halifet Gazi Kümbeti Taçeapısı

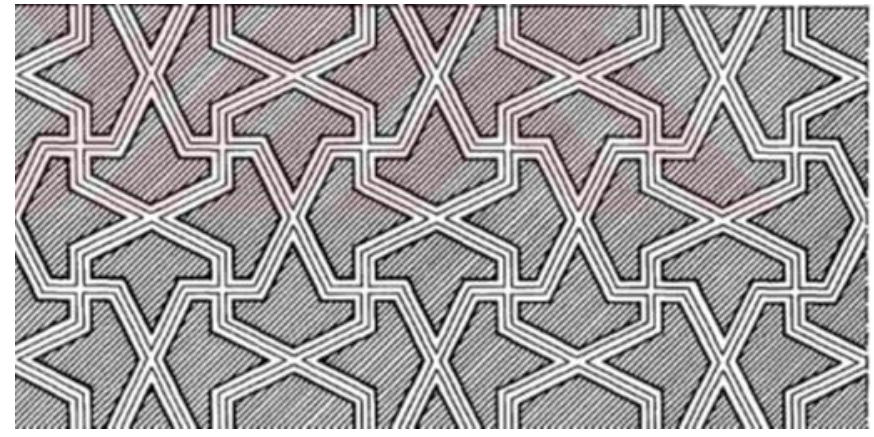

Şekil 10. Amasya, Gümüs Hacı Halil Paşa Medresesi (Y. Demiralp)

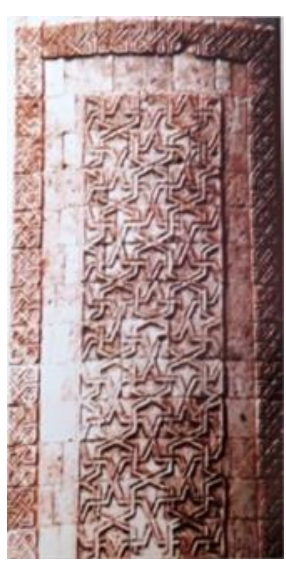

Fotoğraf 22. Diyarbakeır, Şeyh Safa Camii Minaresinden

Birbirini çapraz eksenlerde kesen kırık hatlı şeritlerin düşey ve yatay olarak oluşturduğu aynı zamanda ok uçları meydana getiren "X" motiflerine Osmanlı Dönemine ait Diyarbakır Ali Paşa Camii (1534-1537) minber korkuluğunda, Diyarbakır Melek Ahmed Paşa Camii (1587-1591) minare kaidesinin kuzey 
panosunda ve Diyarbakır Melek Ahmed Paşa Camii (1587-1591) minare kaidesinin kuzey panosunda rastlanmaktadır (Foto: 23) (Baş, 2013, s. 88, Foto: 132).

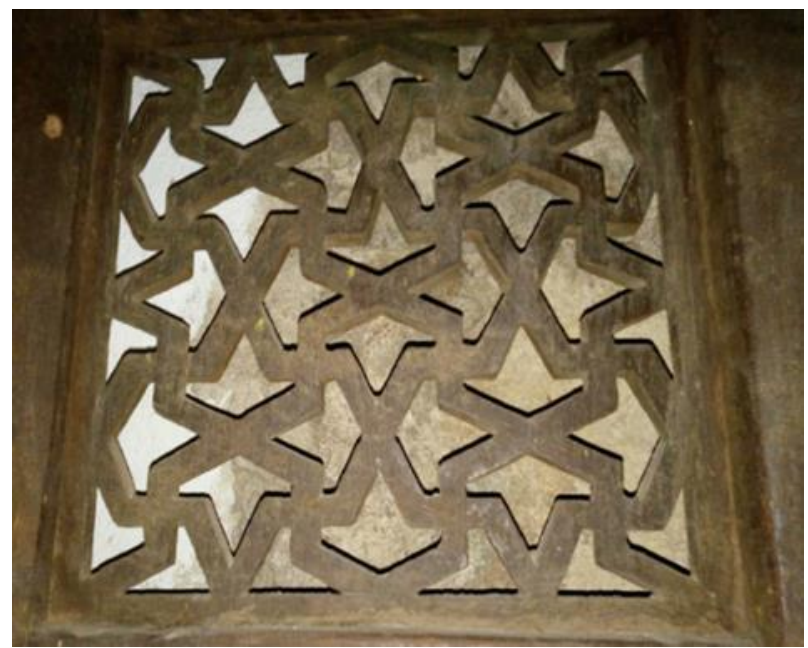

Fotoğraf 23. Diyarbakır Ali Paşa Camii Minber Korkuluğu

Zencerek olarak isimlendirilen bir başka geometrik süslemede çapraz geçmeler "X" şeklini meydana getirmektedirler. Cacabey Medresesinde (1272) Cacabey Türbesinin bulunduğu kuzeydoğu köşesinde yer alan payanda yapının diğger köşelerinde bulunanlardan farklı olarak belirttiğimiz şekilde çapraz şeritlerin geçmeli bir şekilde uç uca tutunarak düşey hatta ilerlediği kabartma bezemeye sahiptir (Foto: 24) (Aslan, 2018, Fotoğraf 42). Aynı şekilde Güroymak Kalenderbaba Kümbeti (13. yy) cenazelik katının üstünde, Erzurum Anonim Kümbetin (14. yy) sekizgen gövdesinin külah altında kabartma şeritler çapraz geçmelerle zencerek motifli bir kenarsuyu halinde dolaşmaktadır(Foto: 25). Erzurum Çifte Minareli Medrese'de (1271) öğrenci odalarından birinde avluya açılan tepe penceresinin çerçevesinde, Ağzıkara Han'ın (1236) avlu taç kapısındaki yan niş sivri kemerlerinde, Konya Sahip Ata Cami (1258) mihrabında mukarnas içlerindeki çini yüzeylerde yer alan bu süsleme I. Ulusal Mimarlık örnekleri arasında Ankara Ulus, Osmanlı Bankasının (1926) birinci kat pencere kemerlerinin hizasında cepheyi dolaşan kalın kenarsuyunda da devam etmektedir (Akdağ, 2019, s. 43).
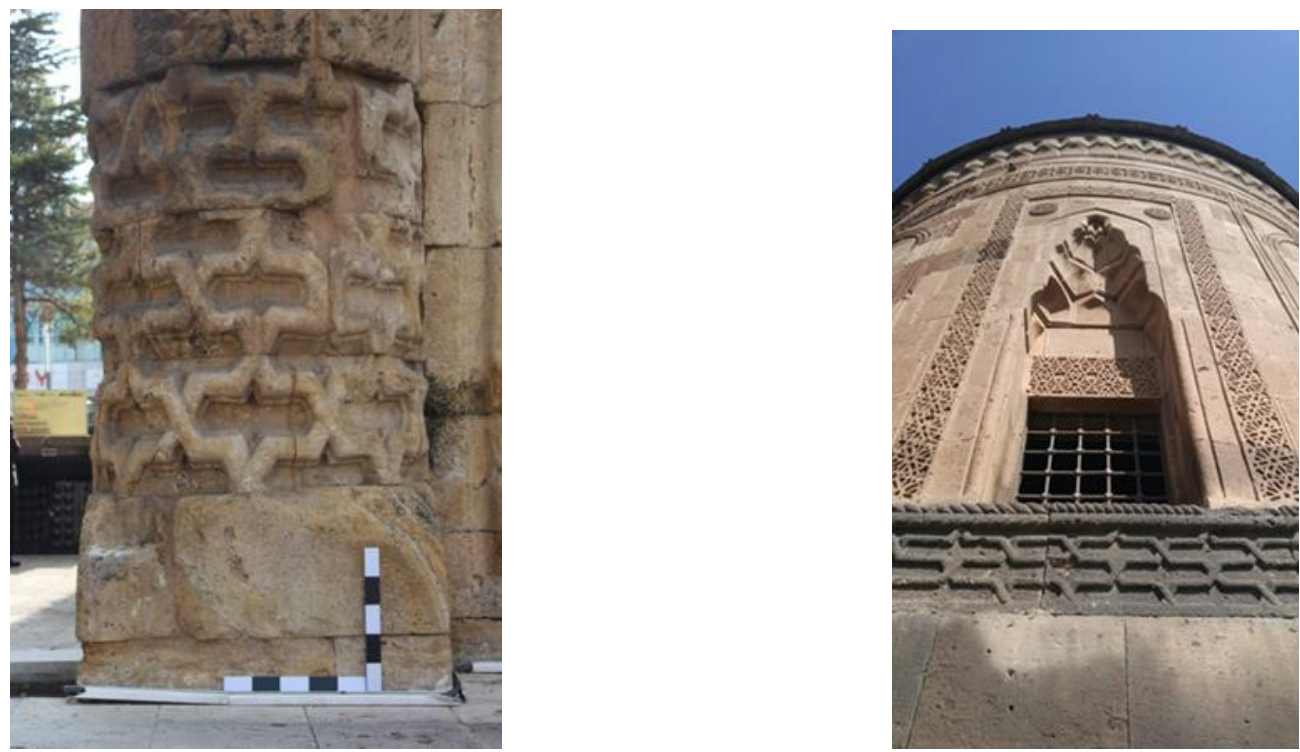

Fotoğraf 24. Cacabey Medresesinde Payanda (Y. Aslan) Fotoğraf 25. Güroymak Kalenderbaba Kümbeti

Özkent Nasır bin Ali yani Orta Türbesinin (1012-13) arka tarafinda duvar yüzeyinde aralarında sekiz köşeli yıldızların "X" şekilli tuğla kabartmalarla yer aldığı süslemenin benzerlerine Büyük Selçuklu zamaninda Isfahanda Sariban Minare,(1130-1155) ile 12.yy'a ait Ali Minaresinin gövdesindeki tuğla süslemelerde rastlanmaktadır. Bu minarelerin gövdelerinde iri şekildeki yıldız motifleri münavebeli olarak çapraz motifler ile geniş bir kuşakta dikkat çekmektedir (Foto: 26, 27). Sekiz kollu yıldızların aralarındaki çapraz motifleri, renkli taşlardan olmak üzere Osmanlı dönemine ait Gaziantep Şeyh Fethullah Camii 
(1563) son cemaat yerine açılan kuzeybatı pencere alınlı̆̆ında, Gaziantep merkezdeki Eyüboğlu Camii (14. yy. ortas1) avlu döşemelerinde, Şanlıurfa Mahmut Nedim Efendi Konağı eyvan döşemesinde varlığını göstermektedir ( Foto: 27, Şekil: 11) (Doğan, 2013, s. 362).

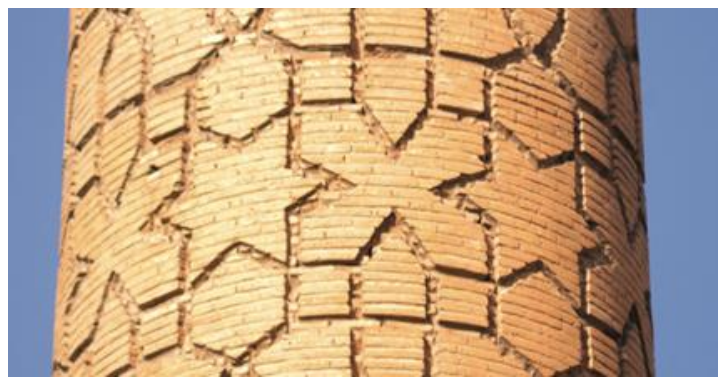

Fotoğraf 26. Isfahan, Sariban Minare

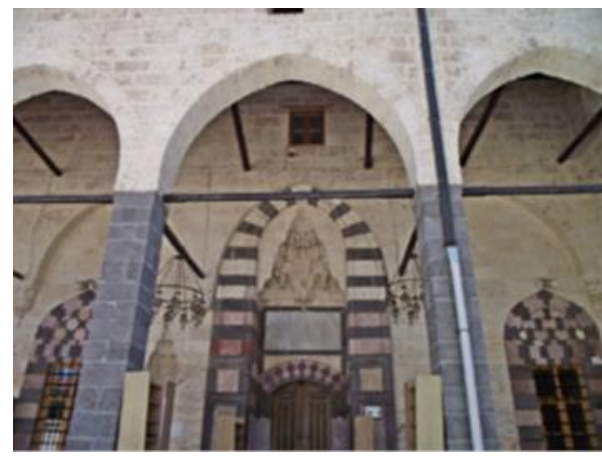

Fotoğraf 27. Şeyb Fethullah Camii Son Cemaat Yeri Şekil 11. Gaz̧iantep, Eyüboğlu Camii

Anadolu Selçuklu yapılarında çapraz şeklin pencere parmaklıklarında oluştuğu da görülmektedir. Konya Kesikbaş Kümbetinde (13. yy) kare şeklindeki cenazelik katın doğu, batı ve güney duvarlarında yer alan pencerelerin çapraz şekilli taş parmaklıklara sahip olduğu, Konya İnce Minareli Medresenin(1264) alç1 içlik pencerelerinde yer alan geometrik geçmelerin merkezinde ise " $\mathrm{X}$ " şeklin yer aldığ1 fark edilmektedir (Foto: 28) (Tanriverdi, 2018, s. 134), (Foto: 29) (Bülbül, 2016). Azerbaycan'da Abseron’a bağlı Merdekan Köyü'ndeki Tuba Şah Mescidi(1481/82) güney cephesinde üst sira pencere şebekesinde "X" motiflerinin yer aldığ1 geometrik bir düzen, Gobustan-Mereze Köyü, Diri Baba Türbesinin (1402)doğu cephesinde ikinci kat pencere şebekesindeki kafes oyma süslemesinde de görülmektedir (Şekil: 12, Foto: 30) (Çağlitütüncügil, 2007, s. 131). 


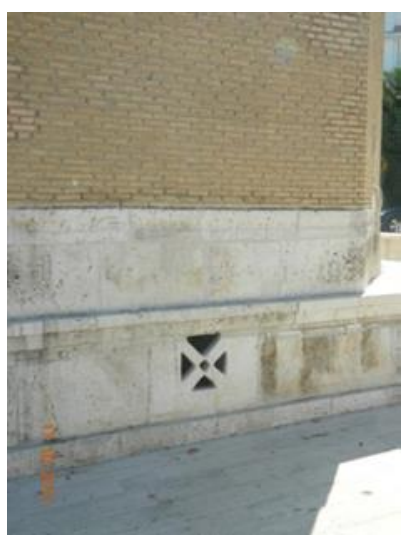

Fotoğraf 28. Kesikbass Kümbeti (Ş.Tanrverdi)

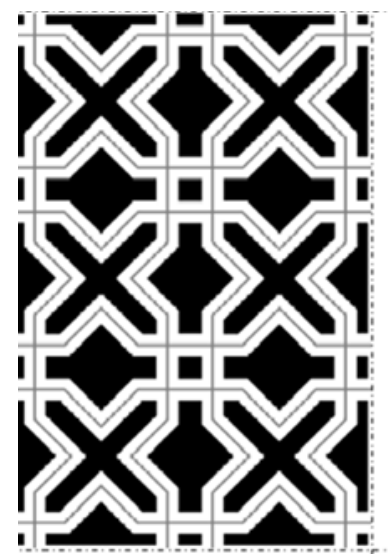

Şekil 12. Abseron-Merdekan Köyü, Tuba Şab Mescidi, Pencere Şebekesi (E. Çağhtütüncil)

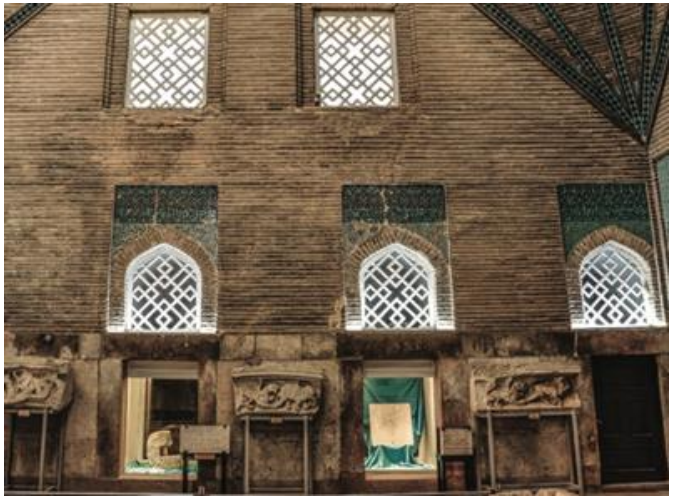

Fotoğraf 29. Konya, Inceminareli Medrese Pencereleri

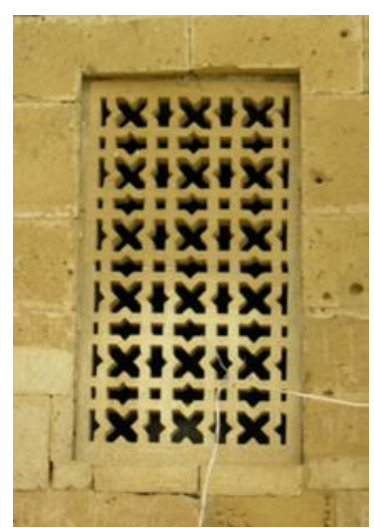

Fotoğraf 30. Gobustan-Mereze Köyü, Diri Baba Türbesi Pencere Şebekesi (E. Çağhtütüncügil)

$\mathrm{X}$ motiflerinin oluştuğu tuğladan bir kenar suyu Konya Kalender Baba Kümbetinde (13. yy) sekizgen gövdesinin üstünde külah altındaki kuşakta karşımıza çıkmaktadır (Şekil: 13), (Önkal, 2006, s. 351-359). Osmanlı devrine ait Geyve İmaret Camii (14. yy) giriş cephesindeki geometrik tuğla süslemeli panonun alt kısmında üç adet çapraz motif yer almaktadır (Demiriz, 1979, s. 499). Dulkadirli veya Memluklü dönemine ait olduğu söylenen Gaziantep Merkez Şirvani Camiinin (14-15. yy) taçkapı alınlığındaki dilimli kemerlerde yer alan motifler arasında küçük kareler içinde bazı araştırmacıların yıldız olarak tanımladıkları "X" şeklinde oyuklar bulunmaktadır (Doğan, 2013, s. 71). Gaziantep Merkez Ağa Camisinin (1554-1559) 1555 de yapılan1799 y1lındaki tamirle yenilenen minaresinin petek kısmı, üzerlerindeki "X" çarpı şekilleri ile taş örgülere sahiptir (Foto: 31) (Doğan, 2013, s. 73). İlk defa 1570’lerde yapılan Gaziantep Hacı Nasır Camii minaresinin şerefe korkuluğunun her kössesi panolar halinde düzenlenmiştir (Foto: 32). Bu panolarda çapraz hatlı şebekeler de görülmektedir (Doğan, 2013, s. 170). 1886 tarihli Gaziantep Belediye Hanı doğu kapısının sivri kemerinin oyma kabartma tekniğiyle işlenmiş olan süslemeleri arasında kabartma "X" motifleri bulunmaktadır (Foto: 33) (Doğan, 2013, Foto: 457-458). 


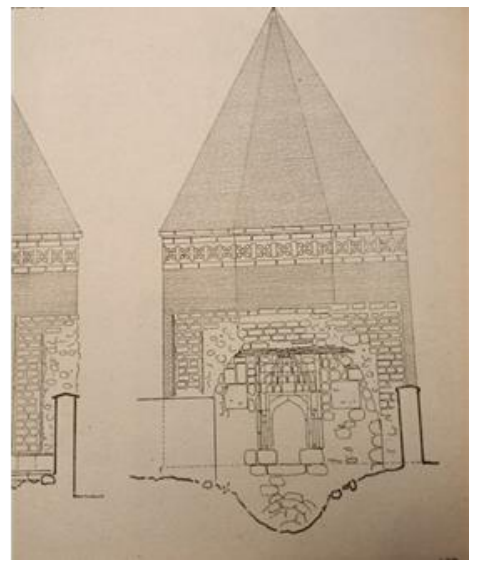

Şekil 13. Konya Kalender Baba Kümbeti (O.C. Tuncer)

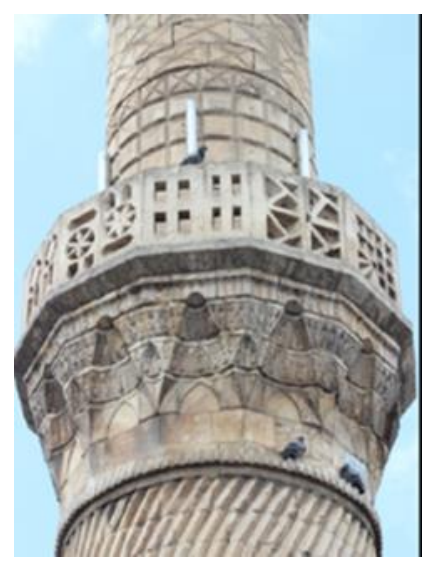

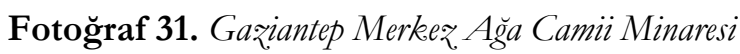

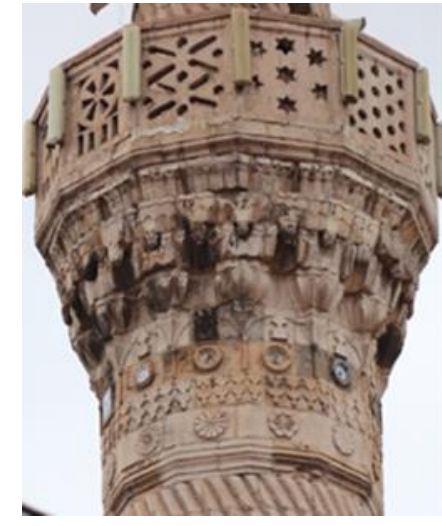

Fotoğraf 32. Gaziantep Hacı Nasır Camii Minaresi

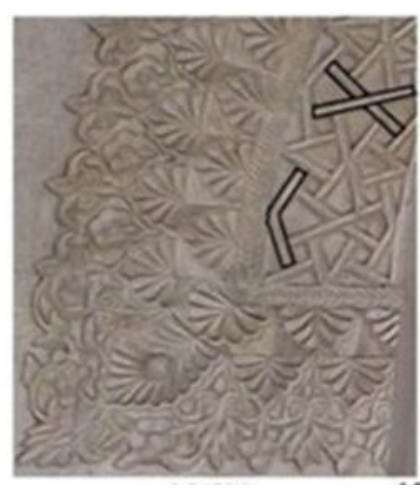<smiles></smiles><smiles></smiles><smiles></smiles>
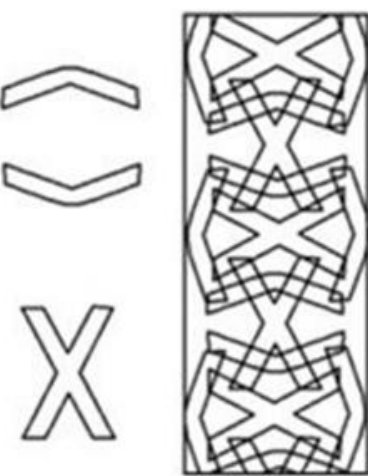

Fotoğraf 33. Hatay Habibi Neccar Camii Tac Kapi Kemerindeki Süslemeler (T. Doğan)

Bakü Cuma Camiinin 15. yy.'da eklendiği düşünülen minaresinde şerefe korkuluğunun taş levhalarında yer alan farklı geometrik süslemeleri arasında çapraz motifler de görülmektedir(Foto: 34) (Çağlitütüncügil, 2017, s. 207). Azerbaycan'da Astara-Pensar Köyü Hacı Teymur Mescidinde (1896) güneybatı köşesindeki minaresinin silindirik gövdesi, yatay ve dikey olarak örülen tuğlaların oluşturduğu çapraz eksenlerde sıralanan eşkenar dörtgenlerden oluşmaktadır ( Çağlitütüncügil, 2017, s. 208), (Şekil: 14). Gövdenin alt kısmında yer alan geniş bir süsleme kuşağ1 " $\mathrm{X}$ " şekilli motiflerin yan yana dizilmesinden meydana gelen geometrik bir kompozisyonla süslüdür (Çağlitütüncügil, 2007, Res. 484; Şek. 4).Yine Azerbaycan Zakatala -Mosul Köyü, Mosul Mescidin (1836) tuğladan sekizgen kaide üzerinde yukarıya doğru daralarak yükselen sekizgen gövdeli, tuğla minaresinin süslemeleri arasında " $\mathrm{X}$ " şekilli motifler de yer almaktadır (Foto: 35). Ayrıca Mescidin güney cephesinde çökertme süslemeler arasında tuğladan "X” motifleri bulunmaktadır (Foto: 36), (Çağlitütüncügil, 2007, s. 178, Res. 367, Res. 368, Şek. 17).

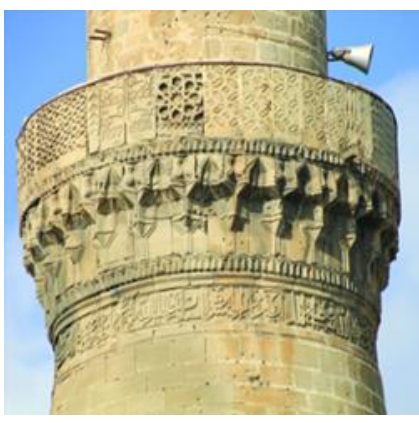

Fotoğraf 34. Bakü Cuma Camii

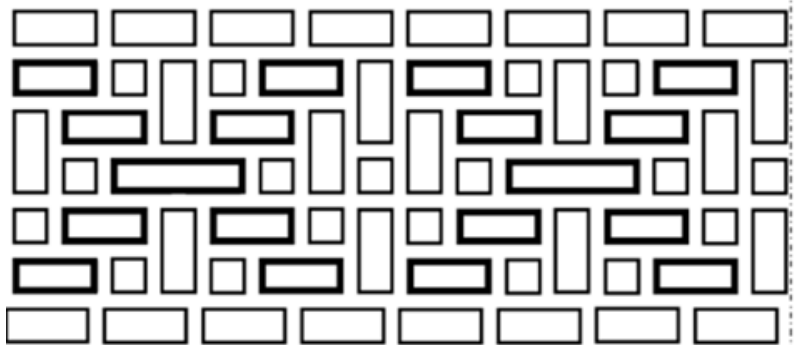

Şekil14. Ažerbaycan, Astara-Pensar Köyü Hacı Teymur Mescidi Minaresinden (E. Çă̆htütüncil) 
İzmir, Salepçioğlu Camii (1895-1906)son cemaat yeri tavan göbeğinde kalemişi olarak sekiz kollu bir yıldız yer almaktadır. Bu yıldızın kolları arasına gelecek şekilde yerleştirilen eşkenar dörtgenlerle oluşturulan ikinci bir sekiz kollu yıldızın eşkenar dörtgenleri içindeki bitkisel süslemelerde Pazırık Halısındaki "Hun Gülü” motifi benzeri görülmektedir(Foto: 37) (Polat, 2011, s. 279). Kartal Amine Hatun Camii (1924) kadınlar mahfili korkulukları ise çapraz yerleştirilen çıtalardan meydana gelmiştir (Makas, 2019, s. 98-100).

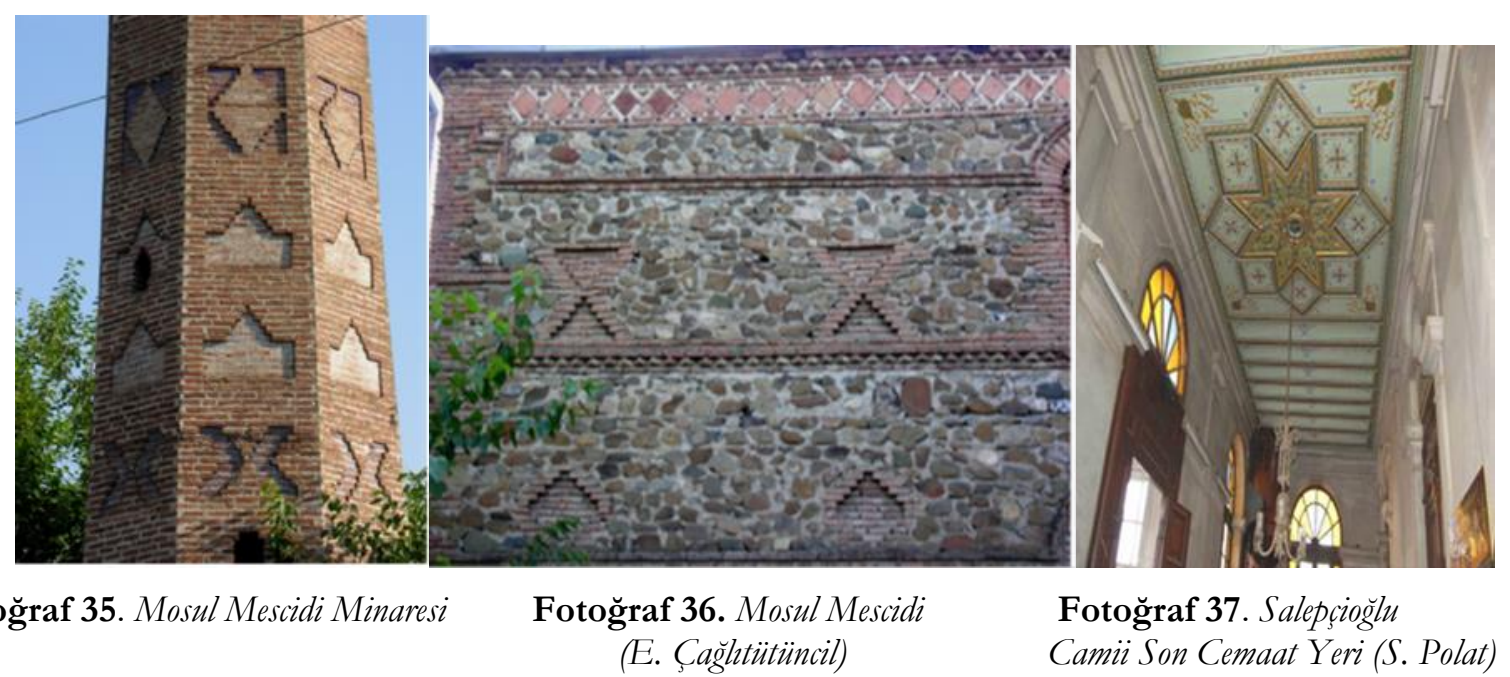

I. Ulusal Mimarlık dönemi eserleri arasında Balıkesir Türk Ocağı Binası ile Balıkesir Vali Konağının( 1926-28) ve Bandırma Maarif Otelinin (1926) balkon korkuluklarında "X" şeklinde ajurlu süslemeler yer almaktadır(Foto: 38, 39) (Yabanc1, 2012, s. 40-55). Şebeke halindeki bu çapraz motifler, kare alanlar içinde kabartma olarak Erkilet Nişancı Mehmet Paşa Cami'nin (1718) batı cephesinde bulunan kuş evinde çatıyı sinırlayan bir kenarsuyu halindedir (Foto: 40). Çapraz şeklin bu motifleri I. Ulusal Mimarlık yapılarından Türkiye İş Bankasının (1929) balkon korkuluklarında ve ikinci kat sütun başlığı üstündeki kare panolarda kabartmalı levhalarda yer almaktadır (Akdağ, 2019, s. 62). Cumhuriyet dönemi I. Ulusal Mimarlık yapılarından Türkiye İş Bankasının (1929) giriş cephesine açılan 2. kat balkonunun korkuluklarında ve Ziraat Bankasının (1926-1929) doğu(ön) cephe giriş bölümünde yer alan ayak kaidesi üzerinde " $\mathrm{X}$ " kabartmalı levhalar bulunmaktadır (Akdağ, 2019, s. 44-91, Şekil: 14)

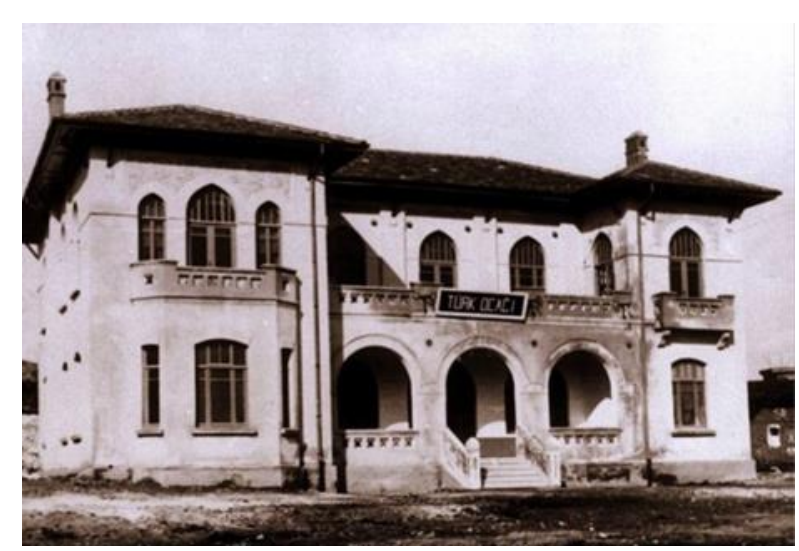

Fotoğraf 38. Balıkesir Türk Ocă̆ı Binası (E. Aydoğan)

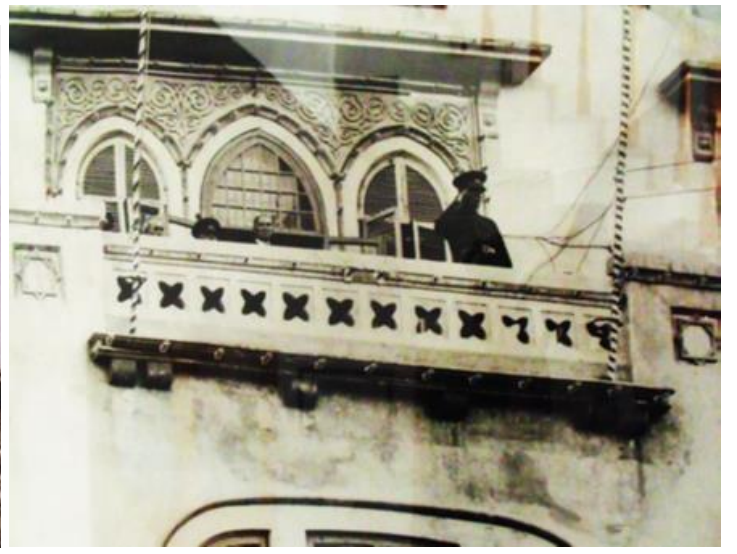

Fotoğraf 39. Ballkesir Vali Konăğ(O. Yabanci) 


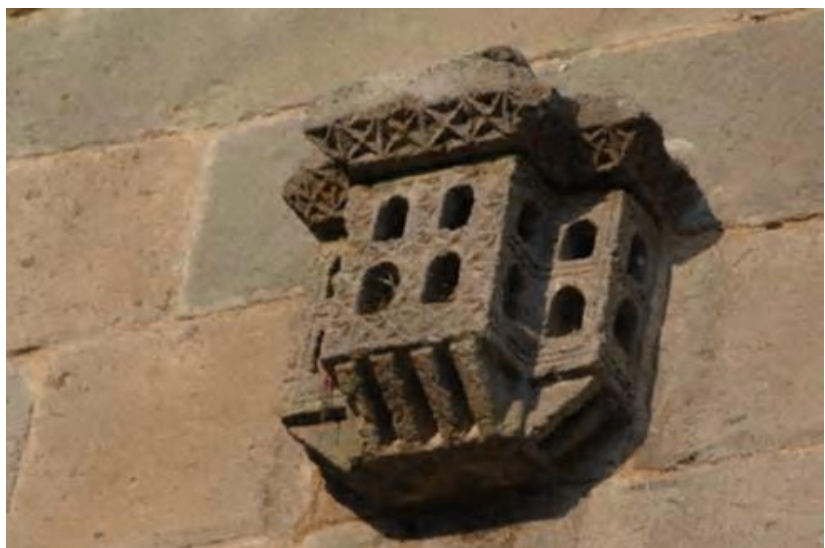

Fotoğraf 40. Erkilet Nisancı Mehmet Paşa Camii Kusevi

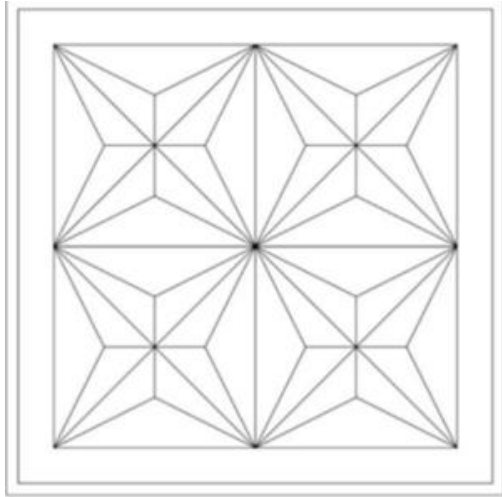

Şekil 14. Osmanl Bankası İkinci kat sütun başh̆̆g üstündeki kare pano (E. D. Bilginer)

\section{Mezartaşlarında Çapraz Motif}

Çapraz şeklindeki motiflerin kimi zaman damga olarak en fazla kullanıldığı yerlerden biri de mezar taşlarıdır. Antalya, Güzeloba Mezarlığında üzerinde "X" şekilleri olan mezar taşları arasında bulunan bir mezar taşında diğerlerinden farklı olarak yer alan Orta ve İç Asya'nın taş babalarını hatırlatan ellerini çapraz tutan kabartma insan figürü ilgi çekmekte (Çoruhlu, 2018, s. 27), yine Antalya'da Barınaklar Mezarlı̆̆ında yer alan bazı mezar taşlarında "X" motifler karşımıza çıkmaya devam etmektedir (Foto: 43), (Çoruhlu, 2017, s. 52, 54, 55).

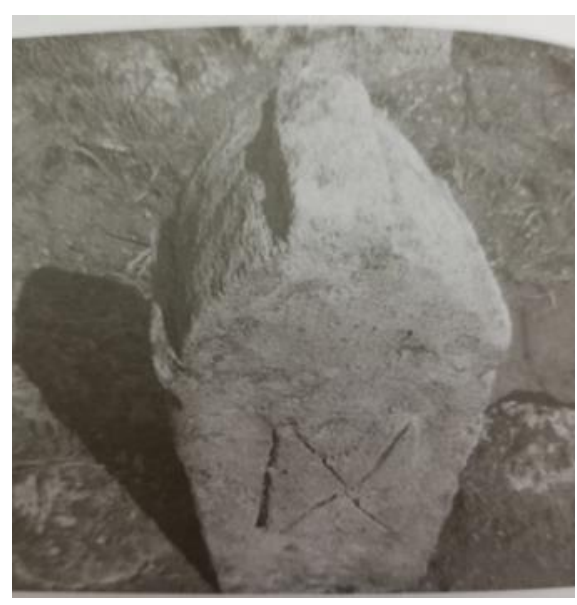

Fotoğraf 41. Antalya, Güzeloba Mezarlı̆̆ndan

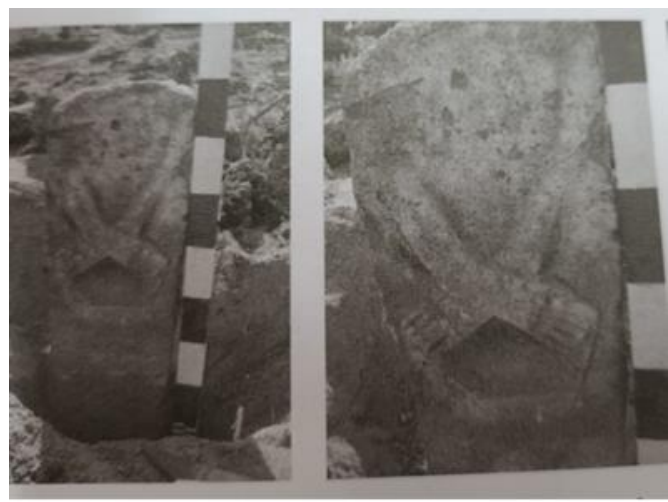

Fotoğraf 42. Güz̨loba Mez̧arlĭğndan
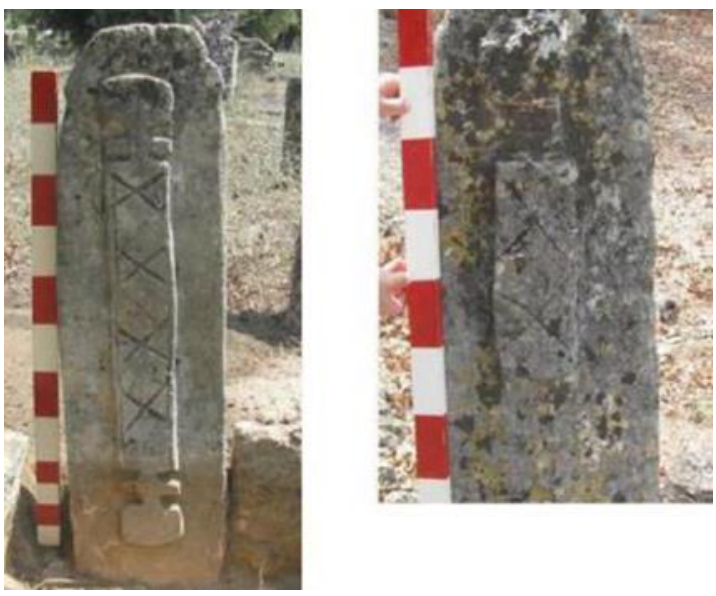

Fotoğraf 43. Antalya Barnaklar Mezarliğından 


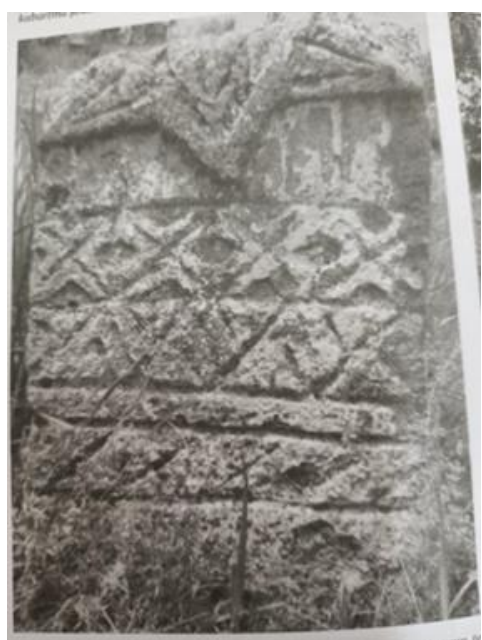

Fotoğraf 44. Güroymak Norşin Mę̧arlğğndan

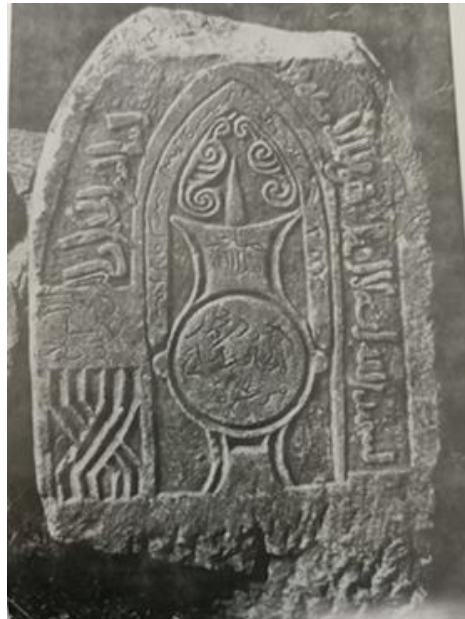

Fotoğraf 45. Kurş̧ebir Aşılk Paşa Türbesi Hą̧iresinden
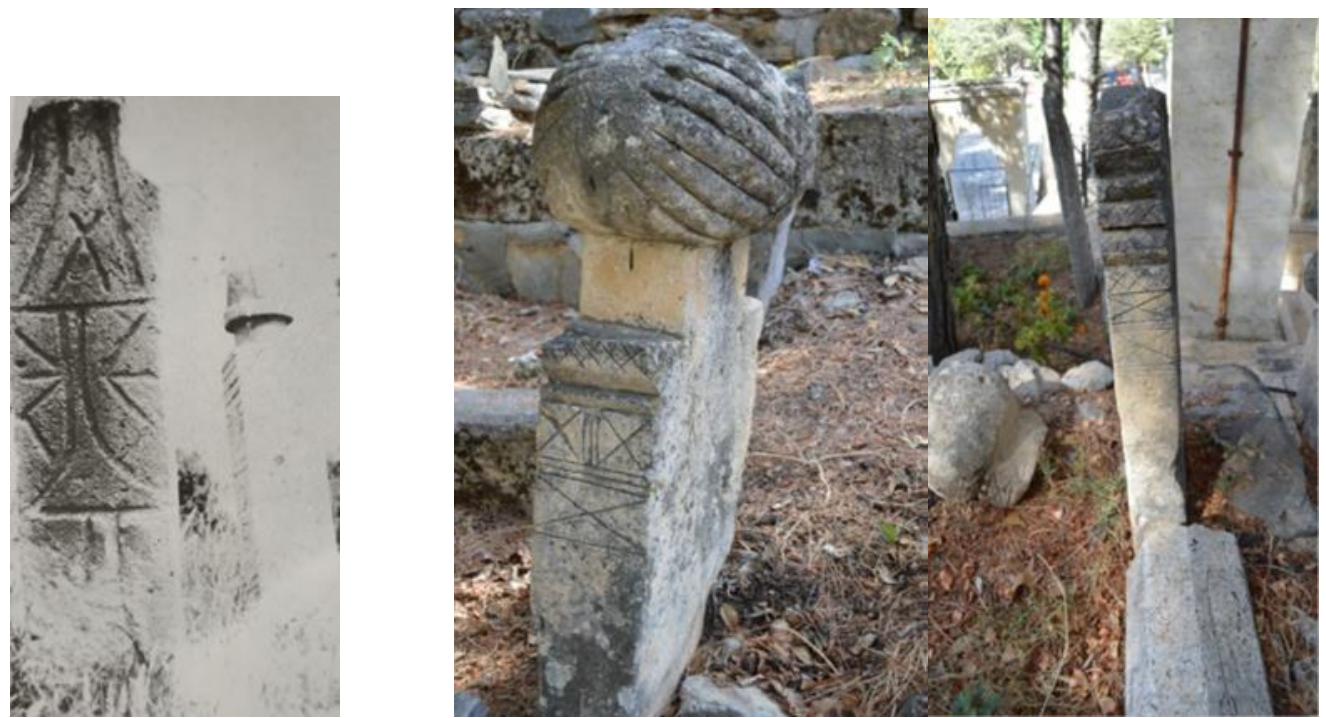

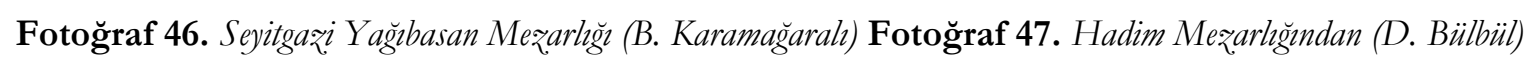

Güroymak Norşin Mezarlığında bulunan dikdörtgen bir mezar taşın gövde kısmında baklava desenleri olarak nitelenen süslemeler çapraz motifler olarak değerlendirilmelidir (Buğrul, 2018, s. 52) (Foto: 44). Kırşehir Aşık Paşa Türbesi haziresindeki kandil motifli mezar taşında " $X$ " şeklinde bir zencereğin parçası gibi duran kabartmanın yer aldığ görülmekte, Seyitgazi Yağıbasan Mezarlığında bulunan 1857 tarihli mezar taşının güney yan yüzündeki " $\mathrm{X}$ " şekil damga olarak belirtilmektedir (Foto: 45, 46) (Karamağaralı, 1992).

Konya Yukarı Hadim Mezarlığında Numan oğlu Abdullah'a ait 1811 tarihli mezarın baş ve ayak taşında çapraz şeklinde az derin oyma motifler bulunmaktadır (Bülbül, 2017, s. 43) (Foto: 47). Konya Yukarı Hadim Mezarlığında bulunan mezar taşlarında kullanılan geometrik süslemeler içinde en yaygın olanının çarp1 " $\mathrm{X}$ " işareti ve onu hem aşağıdan hem de yukarıdan sınırlandıran çizgiler olduğu belirtilmektedir. Ayak ve baş taşı fark etmeksizin kullanılan bu motifin, bazen Zahide Hanım'a ait 1836 tarihli mezar taşında olduğu gibi tek bir çarpı halinde, bazen de 1872 tarihli isimsiz bir mezar taşındaki gibi ikili ve üçlü kompozisyonlar şeklinde kullanıldığı çoğunlukla da mezar taşlarının yan kısımlarında yer aldığ1 görülmektedir (Foto: 48, Şekil: 15) (Bülbül, 2017, s. 142). Malatya Kırkkardeşler Mezarlığındaki mezar taşları arasında bulunan Mahmud'un oğlu üstat Hüsam'ın sandukasında (1391) baş kısmın dış yüzü zikzak motifleri ile ayak kısmının dış yüzü ise kareler içerisine kabartma " $\mathrm{X}$ " motifleri ile süslenmiştir (Foto: 49) (Yavuz, 2019, s. 48). Erzincan Ozanlı Köyündeki bir mezar taşında yine üst üste sıralanmış kare bölümler içinde kabartma olarak "X" şeklinde motifler yer almakta, Erzincan Başköy ve Çamurdere Köylerinde bulunan iki mezar taşında kabartma "X" motifleri kenar suyu halinde çerçeve yapmaktadırlar (Şekil: 16) 
(Özkan, 2000, s. 38, 47). Ayrıca Erzincan Çayırlı, Eşmepınar Köyü mezar taşları arasında 19. yy ve 20. yy’a ait bazı mezar taşlarının benzer özelliklere sahip olduğu fark edilmektedir (Çal, 2007, Foto: 19, 32).

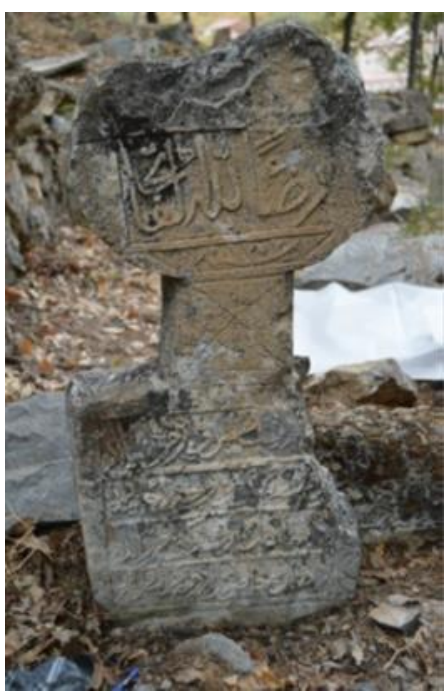

Fotoğraf 48. Zabide Hanm'a Ait Mezar Taşı (D. Bülbül)

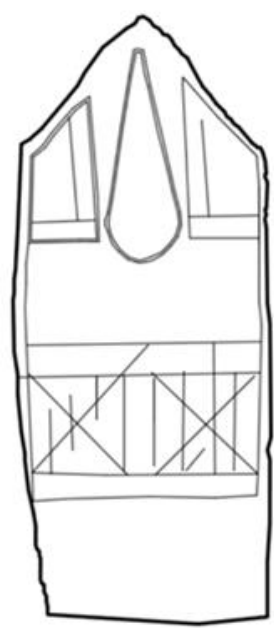

Şekil 15. Isimsiz Mez̧ar Taşı (D. Bülbül)
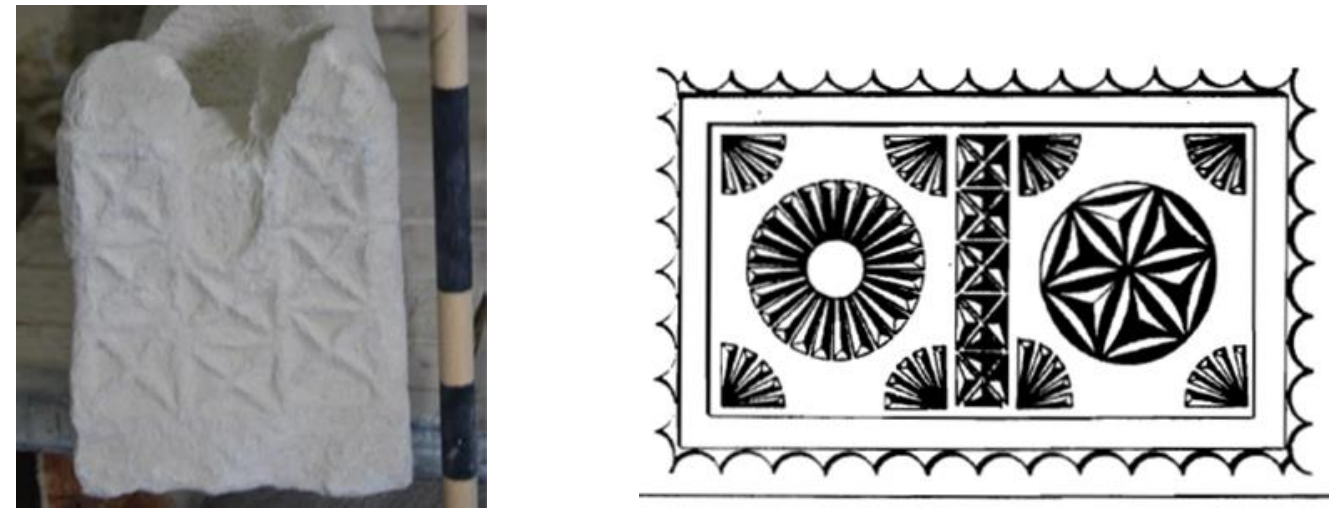

Fotoğraf 49. Mahmud'un oğlu Üstad Hüsam'in sandukası Şekil 16. Oz̧anl Köyü Mezarllğından (A. Çelik)

Karaman Aktekke Camisi haziresinde bulunan kitabesiz mezar taşlarından birinde damga olduğu düşünülen " $X$ " şeklinde bir kabartma yer almaktadır (Foto: 50) (Şahin, 2017, s. 342). Posof Emin Bey Köyü Mezarlığında bulunan mezar taşlarından birinin üzerindeki " $\mathrm{X}$ " motifi, az derin oyma olarak neredeyse taşın bütün yüzeyini kapsayacak bir düzende bulunmaktadır (Foto: 51) (Aktemur, 2017, s. 252).

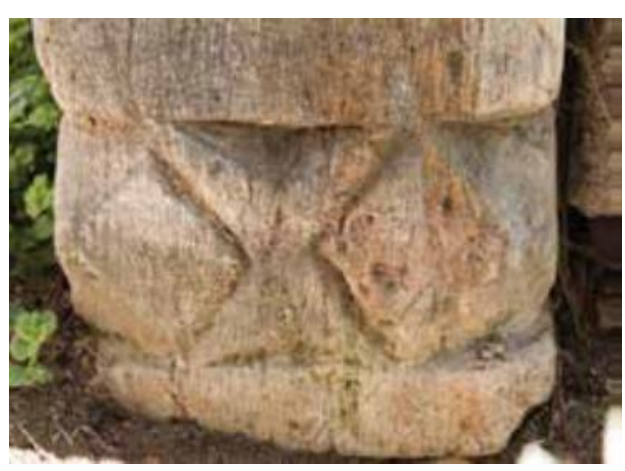

Fotoğraf 50. Karaman Aktekke Camisi Haziresinden

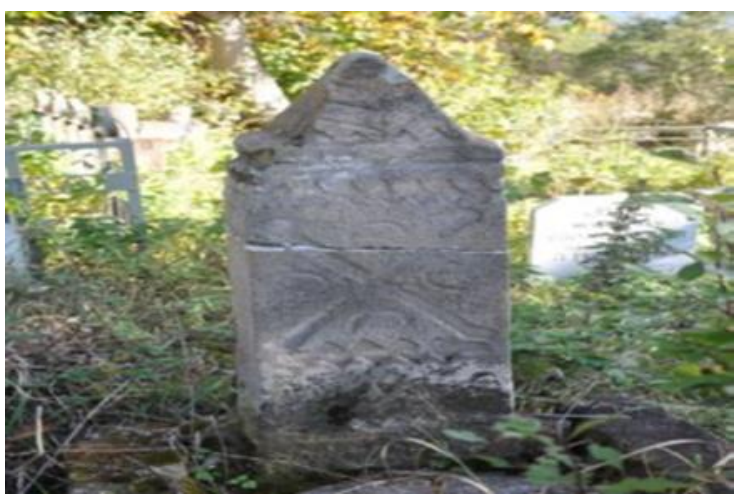

Fotoğraf 51. Emin Bey Köyü Mezarliğından (A. M. Aktemur)

"X" şeklindeki motiflere şahideli mezar taşlarının yanı sıra koç biçimindeki mezar taşlarında da rastlanmaktadır. Erzincan Müzesinde sergilenen biri 1794-95 tarihli, diğeri kitabesiz iki koç heykeli 
şeklindeki mezar taşların gövde kısmında kare içinde bir çapraz motif az derin oyma tekniği ile meydana getirilmiştir (Foto: 52) (Berkli, 2007, s. 73, 74).

Türk sanatında, mezar taşlarında ve mezar yapılarında yer alan " $\mathrm{X}$ " şekillerin bazen damga kimi zaman da bir süsleme elemanı olarak İslam öncesi dönemlerden zamanımıza kadar neredeyse kesintisiz devamlılığının önemli bir durağı da Anıtkabir'de gerçekleşmektedir. Bilindiği üzere Atatürk’ün sekizgen mezar odası mozole'nin birinci katı olan şeref salonundaki sembolik lahit taşının tam altında bulunmaktadır. Burada Atatürk'e ait sanduka, sekizgen zeminin ortasındaki beyaz mermer alanda yer almakta ve bu alanı bir basamak teşkil edecek yükseltide siyah mermerden şerit sınırlamaktadır. Lahdin dışında kalan mezar odasının zeminindeki sekiz bölümünde ise kırmızı mermer üzerinde beyaz çarpraz şeklinde motiflere yer verilmiştir (Kuru, 2017, s. 73, 83, 90) (Foto: 53).

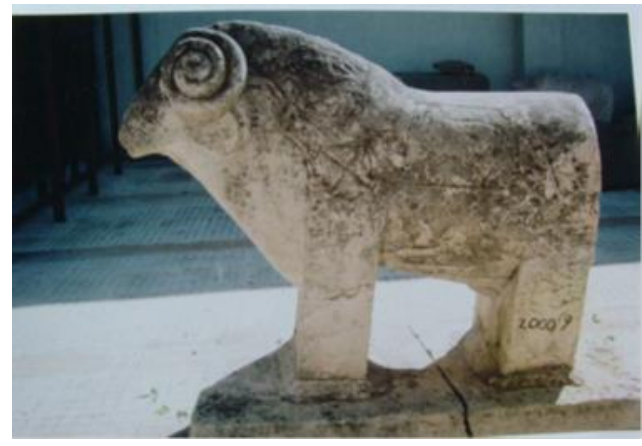

Fotoğraf 52. Eræ̌incan Müzesinden (Y. Berkli)

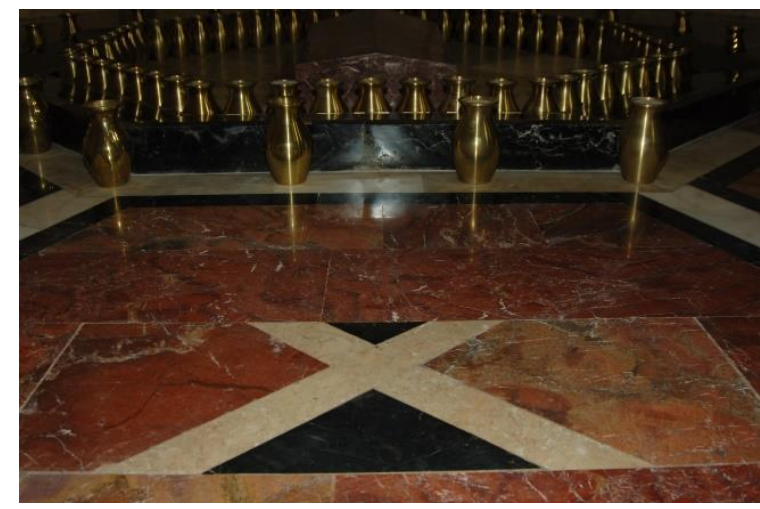

Fotoğraf 53. Atatürk'ün Mez̧ar Odast

\section{Çapraz Motiflerin İkonografisi}

Bu çalışmamızda birbirini çapraz olarak kesen iki çizginin meydan getirdiği "X" şeklindeki motifin kaya resimlerinden yazıtlardan başlayarak Türk Sanatında mimarlık eserlerindeki izleri aranmıs ve bu motifin farklı işlevlerdeki yapılar arasında ağırlıklı olarak camilerde özellikle kümbet ve türbelerde ve mezar taşlarında yer aldığ1 görülmüştür. Orhun Alfabesinde " $\mathrm{D}$ ” sesini veren " $\mathrm{X}$ ”, Avşar, Kızık gibi bazı Türk boylarının damgası olarak da kullanılmıştır (Kırzıŏlu, 1995, s. 68). Moğolistan'da Şiveet-Ulaan ve Orhun anıtlarında olduğu gibi Orta Asya bozkırında Göktürk ve Uygur dönemine ait pek çok yazıtta görülen bu damgalar bağlı oldukları boyların sembolleri olarak üzerinde bulundukları canlı ve cansız varlıkları aidiyet duygusuyla işaretlemişler, İslamiyet’in kabulü sonrası Karahanlı yapılarından itibaren özellikle Selçuklu ve Osmanlı dönemlerinde mimari eserlerde varlıklarını geometrik düzenler içinde sürdürmeye devam etmişlerdir (Duran, 2019, s. 683).

Bazen tek başına çoğu zaman ve yerde geometrik süslemeler arasında, geometrik ağın belirleyici bir unsuru olarak yer alan "X" şeklindeki bu motifin Türk dünyasında İslam öncesi dönemlerinde kullanılmakla birlikte mimarideki asıl yerini ve kullanım şeklini ilk Müslüman Türk devleti Karahanlılar zamanında aldığı görülmektedir. Tuğla duvar örgüsünün derz aralarındaki çapraz ya da ortası ilmekli çapraz şekiller, küçük kare levhalarda yer alan, ya da yatay ve düşey hatlarda birbirine tutunarak alternatif olarak ilerleyen "X" şeklindeki motiflerin oluşturduğu geometrik düzenler daha sonraki y1llarda Selçuklu ve Beylikler dönemlerinde İran, Irak, Suriye, Anadolu, Kazakistan, Kafkasya, Kırım gibi Türklerin yaşadığ1 farklı coğrafyalardaki eserlerinde varlığını sürdürecektir. Osmanlı Mimarisinde taş ve kalemişi süslemeler arasında karşımıza çıkan bu motifin Cumhuriyet Dönemi Ulusal Mimarlık üsluplarında da yerini bulduğu anlaşılmaktadır. Birbirini çapraz kesen iki çizginin oluşturduğu bu şekil kimi zaman bir Oğuz boyunun damgasını ifade etmekte, bazen alışkanlık ya da görsel bellek gereği süslemeler arasında kendine yer bulmaktadır.

Hemen her kültürde genel olarak "X" şekli bilinmeyeni, belirsizliği, iptal etmeyi, yok etmeyi, devre dışı bırakmayı işaret etmenin yanında kullanıldığı yere göre aksi olarak onay vermek anlamına da gelebilmektedir (Kırzıoğlu, 1995, s. 30).

Buraya kadar genel hatlar içerisinde Türk dünyasında, sanatında özellikle mimarlık eserlerinde nerelerde nasıl ve ne şekilde yer aldığ1 incelenen bu motifin sadece bir süsleme elamanı olmanın ötesinde taşıyabileceği anlamlar da düşünülmelidir. Aslında Türk Sanatında sıklıkla kullanılan diğer motiflerin pek çoğunda olduğu üzere "X" şeklindeki bu motifin de Türk Milletinin kültürel hafizasının eserler üzerindeki 
genetik yansıması halinde bilinçli olarak, inançlarla yoğrulan anlamlarıyla karşımıza çıkmış olabileceği dikkate alınmalıdır. Birbirini merkezde çapraz kesen, eşit dört kola sahip olan bu şekil "Tengri Hanın" ve "Umay Ana'nın" sembolü olarak değerlendirilmektedir. Şeklin dört kolunun Tanrının dört yöne hükmünü, aynı zamanda dünyanın dört tarafina güvenerek göğü tutan yay kemerini sembolize ettiği belirtilmektedir. Bu motifin Azerbaycan'da, Anadolu'da, Kuzey Kafkasya'da, Orta Asya ve Doğu Sibirya'da nazarlık karakteri taşıyan koruyucu bir sembol olduğu da ifade edilmektedir (Qurbanov, 2013, s. 30, 37, 50).

Daire içerisinde "X" taşıyan şekil eski Türklerde "Tengri" sembolü olarak kaya resimlerinde sıklıkla karşımıza çıłmaktadır. Daire Tanrının birliğini, evrenin yaratıcısı olduğunu, içindeki "X" işareti ise hâkimiyetini ifade etmektedir. Uygur dönemine ait Moğolistan'daki Karabalgasun Anıtının (762) parçalanmış taç kısmında ağızlarında ay ve güneş simgesi olan birer küre tutan ejder başlarının bir kemer oluşturduğunu ve bu kemeri oluşturan ejderlerin boyun kısmında "X" şeklinde birer kabartmanın fark edildiğini belirtmiştik. Gök kubbeyi temsil eden çift evren (ejder) Türklerde kozmik bir simge olarak hem mezar taşlarında, hem de heraldik bir işaret olarak kullanılırdı. Böylece Alp Bilge Kağan tarafından dikilmiş bu anıtla evreni ve dünya hâkimiyetini simgelemenin yanı sıra Tanriya bağllılk da sunulmaktadır (Esin, 1970, s. 166; Esin, 1972, s. 52-53; Çoruhlu, 2007, s. 284-285).

Günümüzde Kırgızistan'ın bayrağında da sembolleştiği üzere kubbeyi hatırlatan yurt tipi çadırlar, tepesindeki "çangarak", "şanrak" ya da "tüynük " denilen bir çember ortasında "X" şekli ile gökyüzüne açılmaktadır (Foto.:54,55). Türkler için çadırları doğumdan ölüme hayatların yaşandığı ve son bulduğu kutsal mekânlarıdır. Gök kubbeyi devletin, çadırı ise ailenin birer örtüsü olarak düşünen Türkler çadırın kubbesindeki bu deliği göğün kapısı olarak kutsallaştırmışlardır (Ögel, 2010, s. 169). Böylece Türkler yurt tipi çadırlarının tepesine açtıkları bu kapıyla gökyüzünde yer verdikleri Tanrıya ulaşıyor ve ona bağlılıklarını ifade ediyorlardı. Oğuz boylarının bir kısmında olduğu gibi Kırım, Kazak, Nogay Türklerinin de kullandığ1 "X" şeklindeki bu damganın "Şıgarak (çadır) damga" olarak isimlendirilmesi bu işarete yüklenen kutsallığın bir kere daha onayı niteliğindedir (Güllüdağ, 2015, s. 143).

Ayrıca beyaz renkli dört parça üçgen şeklindeki keçenin birleştirilmesiyle meydana gelen Kırgızların millî şapkası kalpağın merkezinde Kırgız çadırındakine benzer nitelikte "X" motifi oluşmaktadır. Bu motifi meydana getiren dört çizginin ortasından çıkan püskülün gökyüzünden gelen nurları insanın beynine yerleştirdiği ve bu nurları güçlü bir şekilde tamamladığı belirtilmektedir (Foto: 56) (Arıkan ve Kallimci 2008, s. 37, 39).

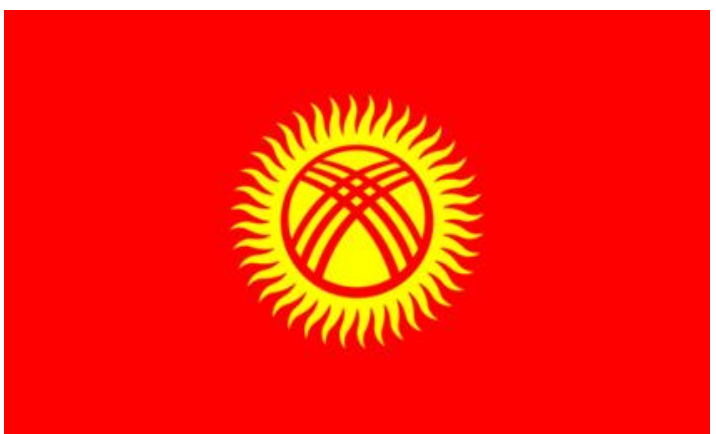

Fotoğraf 54. Kirgızistan Bayră̆ı

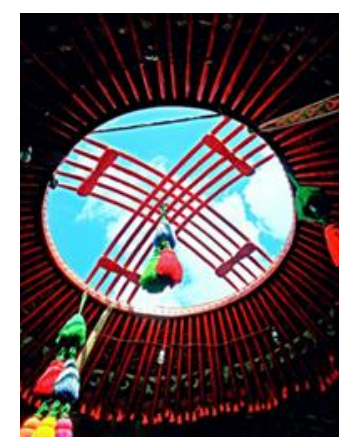

Fotoğraf 55. Yurt Tipi Çadırda Tüynük

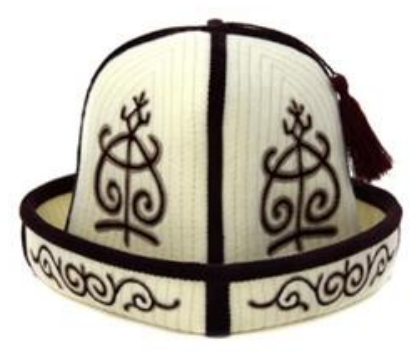

Fotoğraf 56. Kirgz̨ Kalpağg 
Yazılı anıtlarla birlikte Orta Asya coğrafyasında ölen savaşçların anısına dikildiği belirtilen çok sayıdaki "geyikli taşların" üzerlerinde çapraz çizgilerin yer alması, on bin yıl öncesine ait mezarlarda ve Pazırık Kurganlarından (MÖ. 4-3.yy) çıkan bazı mumyalanmış cesetlerde ayakları dizlerine çekilmiş ölülerin ellerinin çapraz olarak gögüslerinin üzerine konmuş vaziyette gömülmesinde ölümün, yok oluşun beraberinde tanriya bağlllı̆ı̆n ifadesi de düşünülmelidir (İskenderzade, 2010, s. 257; Çoruhlu, 2007, s. 33). Öbür dünyaya, ölümden sonra ikinci bir hayatın varllğına, yani bir tür ahirete (sakış künü) inanan Türkler "X" işareti ile bir taraftan ölümü, yok oluşu, öteki dünya inanciyla diğer taraftan var oluşu da sembolleştirmektedir (Gömeç, 2019, s. 90).

Türkler binlerce yıllık birikimlerini, içtenlikle bağlandıkları, inandıkları İslam'ın 1şığında Kur'an'ın yol göstericiliğinde, Hz. Muhammedin söz ve davranışlarında yaşamış ve yaşatmışlardır. Müslüman olduktan sonra da eski inançlarından pek çok unsuru İslamiyet'le kaynaştırarak, zenginleştirerek tarihteki yolculuklarını sürdüren Türkler eserlerinde " $\mathrm{X}$ " motifini bazen damga olarak kullanmakla birlikte çoğunlukla geometrik süslemeler arasında yer vermeye devam etmişlerdir.

İslami değerler arasında "çapraz"ın yeri arandığında Hz. Muhammed'e ait bir hadiste "Kim tek parçalı kumaş içerisinde namaz kılarsa onu iki omuzu arasında çaprazlasın." sözü ile Hac 'da ihrama giren Müslümanların dikişsiz düğmesiz, kefeni hatırlatırcasına sarındığı iki parçadan ibaret beyaz kıyafetin üst kısmının çapraz olarak vücuda bağlanması bu konuda ilk akla gelen olmaktadır (Buhari, Salat 5; Ebu Davud, Salat 78, (627). Böylece Müslümanlar bu ibadetleri sırasında Allah'ın huzuruna en saf, arınmış ve eşit halleriyle çıkmakta, bağlılıklarını sunmaktadırlar. Allah`^n insanlara indirdiği son kutsal kitap olan Kur'an-1 Kerime verilen önem ve ona gösterilen saygının bir ifadesi olarak onu okurken yerden yüksekte, açılır kapanır biçimde yapılmış "X" şeklinde sehpalar olan rahlelerin kullanılması, çapraz şekilde destarlarla sarılan bir yeniçeri başlık türü serdengeçti kavuğu ile İlmiyye sınıfının kıyafet parçalarından olan sarığın, iç başlığının üzerine dışarıdan enli destarlarla çapraz sarılması ve bütün bunların mezar taşlarına da yansitılması "çapraz'ın" İslam inancında zenginleşerek devam eden hikâyesine bazı örneklerdir (Örnek, 2010, s.174; Pakalın, 1993, 57; Pakalın, 1993, 182).

Bir kısım tasavvuf ehli dervişin başına giydiği dört terkli tacın tepedeki birleşim yerinde Kırgız kalpağındaki gibi "X" şeklin oluştuğu görülmektedir (Foto.:57). Bu dört terkli taç'la Allah kelimesinin dört harfine, mhmd olarak peygamberin dört harfine ve İslam'ın dört halifesine işaret edilmektedir ( Atasoy, 2000, s. 175). Buna benzer şekilde Üsküdar'da, Doğancilar Nasuhi Mehmet Efendi’nin Türbesinde(1718) bulunan alçı levhada kabartma olarak Halveti Şabani Tacının dört terk üzerindeki kırk dalının kelime-i tevhid'den nasıl çıktı̆̆ gösterilmektedir (Foto: 58) (Atasoy, 2000, s. 94). Bu levhanın merkezinde yine daire içinde bir " $\mathrm{X}$ " şeklinin meydana geldiği görülmekte, bir taraftan kufi yazı ile "Lâ ilâhe İllellâh, Muhammedün Resûlüllah." Allah'ın birliği, Hz. Muhammed'in onun Peygamberi olduğuna iman belirtilmekte, diğer taraftan merkezdeki "X" şekli ile Allah'a bağlllık ve aidiyet pekiştirilmektedir. Kazakistan Yesi şehrinde bulunan, Hoca Ahmed Yesevi Külliyesinin (1394-1397) batı duvarında ma'k1li olarak yazılmış turkuaz çiniden "Allah Rabbi, Muhammed Nebiyyi”(Allah tanrım, Muhammed peygamberim) yazıları da bunu hatırlatır biçimdedir. Lacivert çinilerden çapraz hatlarla sınırlandırılmış olduğu görülen bu yazı bölümleri yine çapraz olarak uc uca tutunmuş çarkıfelekleri oluşturmakta ve bununla Allah'a ulaşma, kavuşma simgelenmektedir (Foto: 59-60) (Çoruhlu, 2000; Tekin, 2000, s. 357; Çetin, 2017, s. 353-365). 


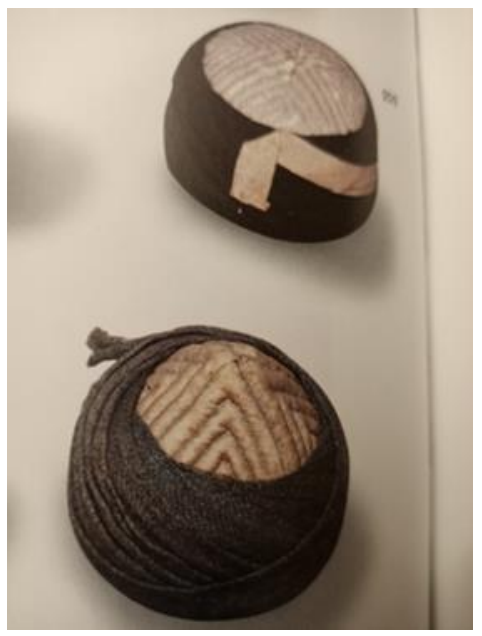

Fotoğraf 57. Dört Terkli Derviş Tacı (N. Atasoy)

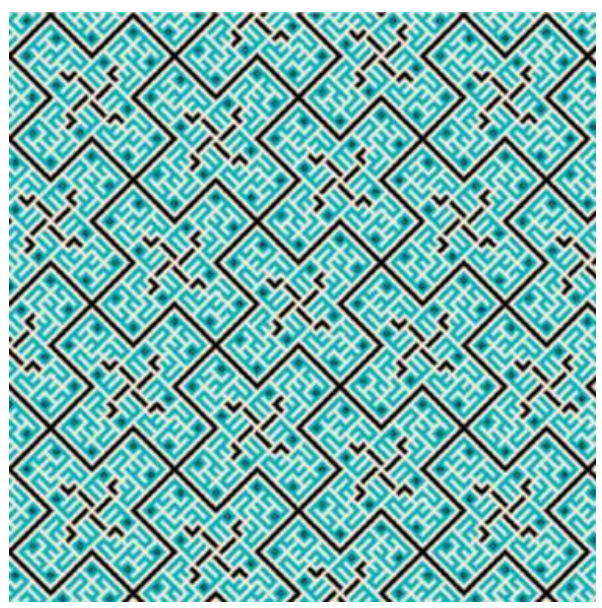

Fotoğraf 59. Yesi, Abmet Yesevi Külliyesi Batı Duvar

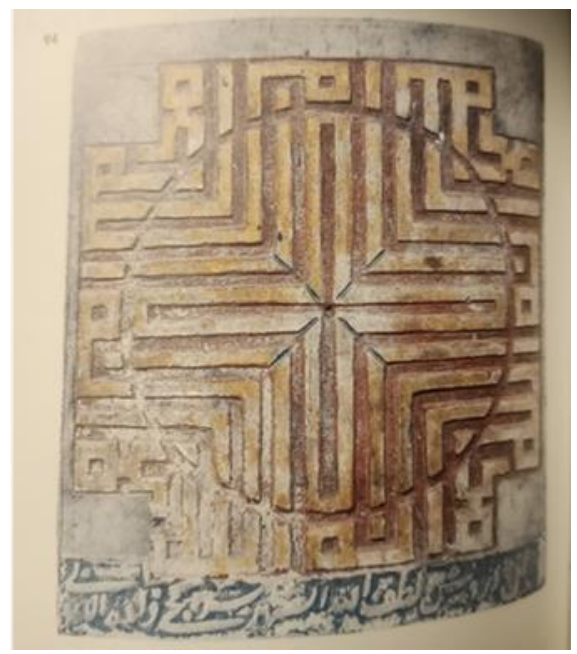

Fotoğraf 58. Nasubi Mehmet Efendi Türbesinde Alçı Levba (N. Atasoy)

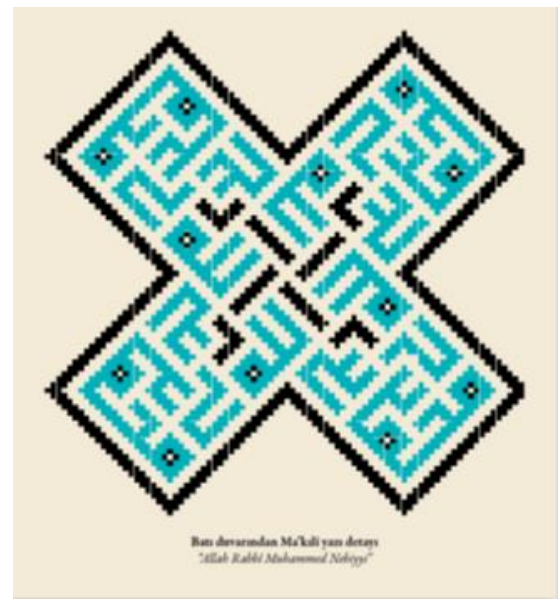

Fotoğraf 60. Yesi, Abmet Yesevi Külliyesi Batı Duvar Detay

Hacı Bektaş Müzesinde bulunan bir resimde ise Bektaşi ozanı Kaygusuz Abdal (14. yy) elleri çapraz bir şekilde göğüs üzerinde ayakta, "dara" durmaktadır (Foto: 61). Bektaşi geleneğinde "dara durmak" iki el göğüste, sağ ayak başparmağ1, sol ayak üzerine konulmuş ve vücut hafif öne eğilmiş vaziyette duaya durmaya denir. Ellerin çapraz bağlandığ1 “dar" yaratıcının huzurunda durduğunu kabul ederek özünü, benliğini ortaya koyup, teslim olmanın adı olmaktadır.

Mevlana Celaleddin-i Rumi’nin vecd ve zevk ile hiçbir kurala bağlı kalmadan yaptığı dönüşten alınan ilhamla düzenlenen semada, her selamın bitişinde durarak ikili üçlü gruplar oluşturan semazenlerin aldıkları niyaz pozisyonunda kollar çapraz olacak şekilde eller omuza konulmakta, sağ ayak başparmağının sol ayak başparmağı üzerine gelecek şekilde olduğu görülmektedir (Bademci, 2018, s. 26, 30). Bu davranışlarda yine Allah'a inanç, bağlllık, teslimiyet, sahiplenme ve "bir olma” söz konusudur. İşte çapraz motifler, sembolleşen bu duyguları farklı tekniklerle ve farklı geometrik düzenler içerisinde üzerinde yer aldıkları Türk Mimarlık eserlerine yansıtmışlardır. 


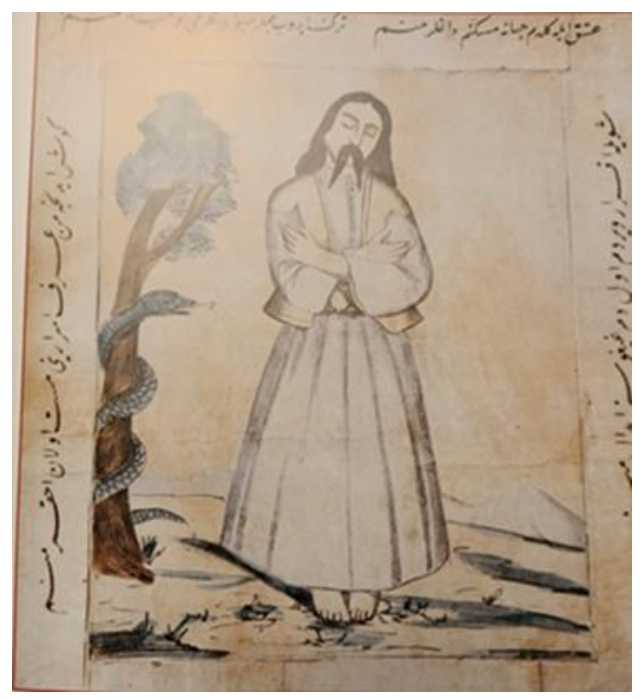

Fotoğraf 61. Kaygusuz, Abdal (N. Atasoy)

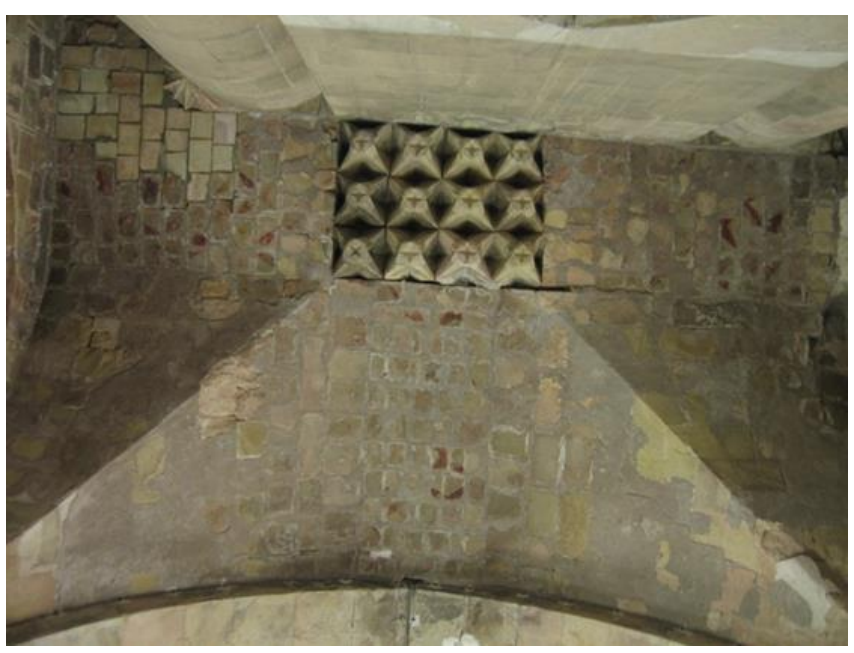

Fotoğraf 62. Divriği Ulu Camii (K. Özkul)

Divriği Ulu Camii (1228) kuzeyinde yer alan ve üzerindeki tüm motiflerin cenneti tasvir etmesi nedeniyle "Cennet Kapısı" olarak isimlendirilen taç kapısı buna güzel bir örnektir. Bu kapıdan içeriye harim kısmına girişte üstteki aynalı tonoz örtünün merkezindeki sarkıtlar, Camiye giren cemaatin üzerine Allah'ın rahmetinin sağanak sağanak yağacağı olarak yorumlanmıştır. Ayrıca içerde okunan Kuran-1 Kerim'in sesini dışarı vermek işlevini de üstlendiği belirtilen bu sarkıtların tepe noktalarında görülen " $\mathrm{X}$ " şeklindeki oyuklar, Allah rızası için ibadetlerin yapıldığı namaz kılınan bu mekâna Allah'ın rahmetini üzerine alarak girmek olmalıdır (Foto: 62) (Özkul, 2020, Resim 66). Çapraz diye tanımladığımız, birbirini verev olarak kesen bu iki çizgi aslında ellerini yukarıya kaldırmış bir insana da işaret etmekte, Allah'a yakarışı, teslimiyeti de hatırlatmaktadır.

Çapraz şekilli bu motif Türk Milletinin belleğinde, üzerinde yer aldığı eserlerle çağları aşarak gelmiş ve en anlamlı var oluşlarından birini de Atatürk'ün Mezar Odasında Anıtkabir'de gerçekleştirmiştir. Mezar Odasının sekizgen zemininde yer alan kırmızı mermer üzerinde beyaz şeritlerin oluşturduğu "X" şeklindeki motiflerle bir kez daha tanı katına yükseliş yansıtılmıs, bir taraftan hayatın sonu, maddi hayatın sona erişi; diğer taraftan manevi hayatın başlangıcı sembolize edilmiştir (Kuru, 2017, s. 89).

\section{Sonuç}

Birbirini çapraz olarak kesen iki çizginin meydan getirdiği "X" şeklindeki motifin Türk Sanat Tarihinde Orta Asya'da başlayan neredeyse günümüze kadar uzanan yolculuğunda özellikle Mimarlık eserlerinde nasıl ve hangi anlamları taşıyarak yer aldığı incelenmiş, camiler, minareler ve mezar yapılarının bu motifin en fazla kullanıldığ1 yerler olduğu görülmüştür. Türk Alfabelerinde kullanılmakla birlikte, bazı Türk Boylarının damgası olmakla birlikte çapraz motiflerin mimari eserlerde geometrik düzenler içinde şekillenerek varlıklarını sürdürmeleri İslamiyet’in kabulü sonrası Karahanlı döneminde başlamıştır. Çapraz motif Selçuklu ve Osmanlı dönemlerinde farklı coğrafyalarda Türklere ait eserlerde bazen tek başına çoğu zaman ve yerde geometrik süslemeler arasında, geometrik ağın belirleyici bir unsuru olarak yer almıs Cumhuriyet Dönemi Ulusal Mimarlık üsluplarında da var olmaya devam etmiştir.

Eski Türk inançlarında "Tengri” sembolü olarak da kullanılan "X" şeklinin Türklerin İslamiyet'i kabulü ile birlikte Allah'a inanç, O’na bağll1ık, teslimiyet, sahiplenme, O'na kavuşma ve O'nda "bir olma"y1 ifade ettiği anlaşılmıştır.

\section{Etik Beyan}

"Türk Mimarisinde Çapraz "X” Motif ve İkonografisi” başlıklı çalışmanın yazım sürecinde bilimsel, etik ve alıntı kurallarına uyulmuş; toplanan veriler üzerinde herhangi bir tahrifat yapılmamış ve bu çalışma herhangi başka bir akademik yayın ortamına değerlendirme için gönderilmemiştir.

\section{Kaynakça}

Akdağ, G. (2019). Ankara'da I. ulusal mimarllk dönemi banka binalarnnda cephe düzeni ve süsleme (1926-1929) (Yüksek Lisans Tezi). Gazi Üniversitesi Sosyal Bilimler Enstitüsü, Ankara. 
Aktemur, A. M. (2017). Posof çevresindeki mezarlıklar ve mezar taşları. The Journal of Academic Social Science Studies, 64, 237-268.

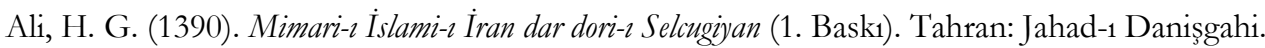

Arıcak, O. T. (1999). Grupla psikolojik danısma yoluyla benlik saygisı ve mesleki benlik saygisınn gelistirilmesi (Doktora Tezi). Marmara Üniversitesi, Sosyal Bilimler Enstitüsü, İstanbul.

Arıkan, M. ve Kallimci, İ. K.(2008). Kutsal Kırgız kalpağı. Turkish Studies International Periodical For the Languages, Literature and History of Turkish or Turkic, 3(2), 33-42.

Aslan, Y.(2018). Kurşehir merkez. Türk devri yapılarnnda taş süsleme (13-14. Yü̈ryl) (Yüksek Lisans Tezi). Selçuk Üniversitesi Sosyal Bilimler Enstitüsü, Konya.

Atasoy, N.(2000).Dervis çeyiz̨i. İstanbul: Kültür ve Turizm Bakanlığ1.

Bademci, F. (2018).Mevleviliğin somut ve somut olmayan kültürel mirasinm bütünleşik korunmasi: Konya örneği (Yüksek Lisans Tezi). Anadolu Üniversitesi, Sosyal Bilimler Enstitüsü, Eskişehir.

Bakırer, Ö. (2002). Anadolu Selçuklu dönemi mimarisinde tuğla örgülerde kullanılan özel derzleme yöntemleri. Prof. Dr. Haluk Karamağaralı Armağam (ss. 1-16). Ankara: Türk Diyanet Vakfi.

Baş, G. (2013). Diyarbakır'daki İslam dönemi mimari yapılarında süsleme. Ankara: Türk Tarih Kurumu Yayınları.

Berkli, Y. (2007). Erzurum ve Eræincan çevresinde görülen koyun, kos ve at biçimli mezar taşlar ve sanat taribindeki yeri (Doktora Tezi). Atatürk Üniversitesi Sosyal Bilimler Enstitüsü, Erzurum.

Bozkurt, O. (2016). Osmank Beyliği dışında batı Anadolu beyliklerinde mimari süsleme (Yüksek Lisans Tezi). Ege Üniversitesi Sosyal Bilimler Enstitüsü, İzmir.

Buğrul, H. (2018). Kaya resimlerinin Van Bitlis Hakkari yöresi mezartaşları üzerindeki izleri. 2. Uluslararası Avrasya Türk Sanatlar Kongresi Bildiriler,2-5 Aralık 2015, (39-66). İstanbul.

Bülbül, B. (2016). Anadolu Selçuklu Dönemi yapılarnmn restorasyonunda özgünlük ölçütü- Konya İnce Minareli Medrese örneği (Doktora Tezi). Gazi Üniversitesi, Fen Bilimleri Enstitüsü, Ankara.

Bülbül, D. (2017). Hadim mezar taşlar (Yüksek Lisans Tezi). Selçuk Üniversitesi, Sosyal Bilimler Enstitüsü Konya.

Cezar, M. (1977). Anadolu öncesi Türklerde sebir ve mimarlı. İstanbul: Türkiye İş Bankası Yayınları.

Çağlıtütüncügil, E. (2007). Ažerbaycan'daki Islâm dönem yapılarnda süsleme (Doktora Tezi). Ege Üniversitesi, Sosyal Bilimler Enstitüsü, İzmir.

Çağlitütüncügil, E. (2017). Bakü Cuma Camii. Cihannüma Tarih ve Coğrafya Araştırmalar Dergisi, III(2), $27-64$.

Çal, H. (2007). Erzincan Çayırlı Eşmepınar köyü mezar- mezartaşları. Sanat Taribi Araştırmalar, Prof. Dr. Haşim Karpuza Armağan (ss. 125-154). Konya.

Çam, N. (1989). Gaz̨iantep Şeyh Fethullah külliyesi. Ankara: Kültür Bakanlığı Yayınları.

Çeşmeli, İ. (2005). Orta Asya camilerinde tipoloji (Doktora Tezi). Yıldız Teknik Üniversitesi Fen Bilimleri Enstitüsü, İstanbul.

Çetin, Y.(2017).Türk-İslam bezeme sanatında gamalı haç (svastika) ile çarkıfelek motiflerinin köken ve ikonografik anlamları üzerine bir değerlendirme. Social Sciences Studies Journal, 3(8), 353-365.

Çoruhlu, Y. (2000). Türbenin mimari özelliği-kesenenin arhitekturalık erekşeliği, İçinde, Türkistan’ın Piri Hoca Abmet Yesevi ve Külliyesi - Turkıstannın Pır Koja Abmet Yasaui Jane Gımaratı (ss. 59-87). Ankara: TIKKA.

Çoruhlu, Y.(2007) Erken devir Türk sanatı. İstanbul: Kabalc1 Yayınc1lı.

Çoruhlu, Y.(2018). Antalya, Güzeloba mezarlı̆̆1 nakışlı şekilli simgeli mezartaşları. 2. Uluslararası Avrasya Türk Sanatlar Kongresi Bildiriler (14-38).İstanbul:Mimar Sinan Güzel Sanatlar Üniversitesi.

Demiralp, Y. (1997). Erken dönem Osmanl medreseleri (1300-1500) (Doktora Tezi).Ege Üniversitesi, Sosyal Bilimler Enstitüsü, İzmir.

Demiriz, Y.(1979). Osmanl Mimarisinde süsleme erken devir I. İstanbul: Kültür Bakanlığ1.

Doğan, T. (2013). Gazৃiantep Türk İslam dönemi mimari süslemeleri (Doktora Tezi). Van Yüzüncü Yıl Üniversitesi Sosyal Bilimler Enstitüsü, Van.

Dönmez, M., Çelik, H. ve Armağan, H. (2018). Alevilik-Bektaşilikte dar. Türk Kültürü ve Hacı Bektaş Veli Araştırmalar Dergisi, 15,183-198.

Duran, R. (2019). Motiflere dönüşmüş Türk damgaları -geometrik motiflere farklı bir bakış. Akdeniz. Sanat Dergisi, 13(23), 679-698.

Esin, E. (1970). Selçuklu sanatı evren tasvirinin Türk ikonografisinde menşeleri. Selçuklu Araştırmalar Dergisi, 161-182.

Gömeç, S. Y. (2019). Eski Türk dininin temel özellikleri. Türk Taribi Arasstrmalarn Dergisi / Journal of Turkish History Researches, 4(1-Prof. Dr. Bahaeddin Ögel Say1s1), 84-123.

Güllüdağ, N. (2015). Türklerde damga geleneği ve Nogay Türklerinin damgaları üzerine bir inceleme. Avrasya Uluslararasi Arastırmalar Dergisi, 3(6), 132-150.

Heiranpour, S. (2019). İran'm batısındaki Büyük Selçklu dönemi eserleri (Doktora Tezi).T.C. Atatürk Üniversitesi, Sosyal Bilimler Enstitüsü, Erzurum.

İmankulov, D. (2005). Monumentalnaya arbitektura yuga Kirgı̨stana. Bişkek.

İskenderzade, L. A. (2010). Göktürk dönemi insan figürlü taş anıtlar. Selçuk Üniversitesi Sosyal Bilimler Enstitüsü Dergisi, 24, 255-269.

Karamağaralı, B. (1992). Ablat mezartaşlar. Ankara:T.C. Kültür Bakanlığ1.

Kırzıŏglu, N. G. (1995). Altaylardan Tuna boyuna Türk dünyasında ortak motifler. Ankara: Kültür Bakanlı̆̆1. 
Koshenova, G. (2013).Kazakistan, Taraz. / Talas şehrindeki türbeler (Yüksek Lisans Tezi). Gazi Üniversitesi Sosyal Bilimler Enstitüsü, Ankara.

Kuru, A. Ç. (2017). Anıtkabir'deki renkli taş süslemeler-ikonografik bir yaklaşım. Sanat Taribi Dergisi, XXVI, 69-93.

Makas, K. N. (2019). Konya Amber Reis camii ve I. ulusal mimarlı dönemi camileri içindeki yeri (Yüksek Lisans Tezi). Yıldız Teknik Üniversitesi, Fen Bilimleri Enstitüsü, İstanbul.

Ögel, B. (2010). Türk mitolojisi. C. II, (4. Baskı). Ankara: Türk Tarih Kurumu Yayınları.

Ölmez, M. (2012). Orhon-Uygur hanlı̆ğ dönemi Moğolistan'daki eski Türk yaz̨tları. Ankara: Bilge Su Yayınları.

Önkal, H. (2006). Türbeler. İçinde Bilici, K. (Edt). Anadolu Selçklu ve Beylikeler Dönemi Uygarlluğ 2 (ss. 351-359). Ankara: Kültür ve Turizm Bakanlığı Yayınları.

Örnek, D. (2010). Türk el sanatlarından rahle. Vakıflar Dergisi, 32, 174-180.

Özkan, H. (2000). Erzincan ve çevresinde Orta Asya Türk geleneğini sürdüren bezemeli mezar taşları. Atatürk Üniversitesi Türkiyat Araştirmalarn Enstitüiü Dergisi, 15, 31-47.

Özkul, K. (2020). Sivas Divriği ulu cami ve darüşşifası bezemeleri. Uluslararası İdil - Ural ve Türkistan Araştırmalar Dergisi (Ijvuts), 2(3), 56-81.

Pakalın, M. Z.(1993). Serdengeçti kavuğu. Osmanl Tarih Deyimleri ve Terimler Sözlüğ̈̈, C.III. Ankara: Milli Eğitim Bakanlığ Yayınları.

Pakalın, M. Z. (1993). İlmiye kıyafeti. Osmanl Tarih Deyimleri ve Terimler Sözlïğü, C. II, Ankara: Milli Eğitim Bakanlı̆̆1 Yayınlar1,

Polat, S. (2011). İmir'deki gec dönem Osmanl camileri (Yüksek Lisans Tezi). Selçuk Üniversitesi Sosyal Bilimler Enstitüsü, Konya.

Qurbanov, A. (2013). Damğalar, ramz̧łr... manimsamalar. Bak1: Strateji Araştırmalar Merkezi.

Rustamova, M. (2019). Karahanle devri mimarisi ve bezemeleri (Doktora Tezi). Marmara Üniversitesi Sosyal Bilimler Enstitüsü, İstanbul.

Somuncuoğlu, S. (2010). Sibirya'dan Anadolu'ya taştaki Türkler. İstanbul: İlke Yayınları.

Sözen, M. (1971). Diyarbakır'da Türk mimarisi. İstanbul: Diyarbakır'ı Tanıtma ve Turizm Derneği Yayınları.

Şahin, H. (2017). Karaman Mader-i Mevlana (Aktekke) Camisi haziresinde bulunan mezar taşları. Türk Dünyası Dil ve Edebiyat Dergisi, Turkish World, Journal of Language and Literature, 44, 297-343.

Tanrıverdi, Ş. (2018). Türklerde mez̧ar mimarisinin Anadolu Selcuklu dönemi Konya kümbetleri üzerinden tipolojïk irdelenmesi (Yüksek Lisans Tezi). Gazi Üniversitesi, Fen Bilimleri Enstitüsü, Ankara.

Tekin, K. H. (2000). Hoca Ahmed Yesevi türbesi (Yüksek LİSANS Tezi). Hacettepe Üniversitesi, Sosyal Bilimler Enstitüsü, Ankara.

Yabanc1, O. (2012). Çanakkale ve Balıkesir yöresinde I. ulusal mimarlık akımı (Yüksek Lisans Tezi). Çanakkale Onsekiz Mart Üniversitesi, Sosyal Bilimler Enstitüsü, Çanakkale.

Yavuz, S. (2019). Malatya Kırkkardeşler mez̧arlğındaki mez̧ar taşlar (Yüksek Lisans Tezi). Necmettin Erbakan Üniversitesi, Sosyal Bilimler Enstitüsü, Konya.

\section{EXTENDED ABSTRACT}

In this study, the traces of the "X" shaped motif, which is brought together by the two lines crossing each other, are searched for the traces of architectural works in Turkish Art starting from the inscriptions of the rock, and this motif was found to be found in mosques, especially in the tombs and tombstones. "X", which gives the sound "D" in Orkhon Alphabet, was also used as the stamp of some Turkish tribes such as Avşar and Kızık. These stamps, which are seen in many inscriptions belonging to the Göktürk and Uyghur eras in the Central Asian steppe, as in the Monuments of Şiveet-Ulaan and Orhun in Mongolia, marked the sense of belonging to the living and inanimate beings on which they belonged, especially after the acceptance of Islam, especially from the Seljuks. During the Ottoman and Ottoman periods, they continued their existence in geometrical order in architectural works.

Sometimes, it is seen that this motif, which is " $\mathrm{X}$ " shaped as a determinant element of the geometric network, is among the geometric ornaments, most of the time and place, but it was used in the pre-Islamic period in the Turkic World, but it took its place in architecture during the first Muslim Turkish state Karahanli. Cross or middle looped cross shapes between the joints of the brick masonry, geometrical layouts formed in small square plates or alternating by holding them on horizontal and vertical lines, alternating in alternate periods, Iran, Iraq, during the Seljuk and Beylik periods, It will continue its existence in works in different geographies where Turks live such as Syria, Anatolia, Kazakhstan, Caucasus and Crimea. "X" motifs have given the most meaningful examples on the walls of the tomb of Hoca Ahmed Yesevi in the city of Kazakhstan Yesi in the Timurlu period and in the grave room of Atatürk in Anitkabir in Ankara.

It is understood that this motif, which is among the stone and hand-carved ornaments in Ottoman Architecture, has also found its place in the National Architecture styles of the Republican Period. This 
shape, which is formed by two cross-cutting lines, sometimes expresses the stamp of an Oghuz tribes, and sometimes finds itself among the decorations due to habit or visual memory.

In almost every culture, the "X" shape in general can mean the unknown, uncertainty, cancellation, destruction, deactivation, as well as giving approval otherwise, depending on where it is used. In this study, it was thought that this motif, which examined how and in which way it takes place in the Turkish world, in the art, especially in architectural works, may have meanings beyond just an element of decoration. It is taken into consideration that this motif, which is in the form of "X", as in many other motifs frequently used in Turkish Art, may have appeared intentionally with the beliefs kneaded with beliefs if the cultural memory of the Turkish Nation is reflected on the works.

In ancient Turkish beliefs, this shape, crossing each other at the center and having four equal arms, is considered as the symbol of "Tengri Han" and "Mother of Umay". It often appears in rock paintings. The circle indicates the unity of God, the creator of the universe, and the "X" sign in it indicates its domination. Turks who believed in the next world, the existence of a second life after death, a kind of hereafter, with this motif, from the Hun period kurgans, dormitory tents, deer stones, monuments, the death of the other world, on the other hand they appear to symbolize their existence and their attachment to God.

Under the guidance of the Qur'an, in the light of Islam, which Turks sincerely believe in, they believe in, and their thousands of years of experience,. They lived and lived in the words and behaviors of $\mathrm{Hz}$. Muhammad.

After becoming a Muslim, Turks, who continued their journey in history by fusing and enriching many elements of their old beliefs with Islam, continued to be among the geometrical ornaments, although they sometimes used the "X" motif as a stamp in their works.

It is seen that these two lines, which are fed with the Islamic Sufism, and which are defined as the "Cross", which is located in the clothes of the Dervishes and their prayers, actually point out to a person who raised their hands and reminded them of Allah. In short, belief, commitment and surrender to God is explained with a cross motif. It understood that the shape of "X", which is also used as the symbol of "Tengri" in ancient Turkish beliefs, means belief in God, devotion, submission, ownership, meeting with Him and "becoming" in Him with the acceptance of Turks to Islam. 